\title{
26
}

\section{ANTIBIOTIC USE DURING AN INFLUENZA PANDEMIC: DOWNSTREAM ECOLOGICAL EFFECTS AND ANTIBIOTIC RESISTANCE}

\author{
AQ1 Andrew C. Sin ${ }^{1}$ And Heike SchmitT ${ }^{2}$ \\ ${ }^{1}$ Center for Ecology ôy Hydrology, Wallingford, United Kingdom \\ ${ }^{2}$ Institute for Risk Assessment Sciences, IRAS, Utrecht University, Utrecht, The Netherlands
}

The years 2009-2010 saw the first pandemic virus in several decades. Only in retrospect has the low pathogenicity of the virus been able to be confirmed. The pandemic saw as many deaths per capita as a seasonal influenza virus, but with the significant difference that the young ( $<18$ years) were atypically impacted over those $>18$ years old (Kamigaki and Oshitani, 2009). Pharmaceuticals played an important part of health care during the influenza pandemic. Many nations implemented huge stockpiles of antivirals in response to the pandemic, but owing to the low pathogenicity of the virus, there was a negligible increase in existing antibiotic use over interpandemic usage. However, current estimates for antiviral and antibiotic use during a moderat $\equiv$ severe influenza pandemic are without historical precedent (Singer et al., submated). Here we discuss the environmental and human health implications of a moderate or severe influenza pandemic with regard to Tamiflu itself and the use of antibiotics to treat secondary bacterial infections. Antibiotic use will be framed in the context of existing paradigms of antibiotic treatment and how these practices already contribute to human and environmental hazards and how these hazards might be minimized in the event of a moderate or severe influenza pandemic.

Antimicrobial Resistance in the Environment, First Edition.

(C) 2011 John Wiley \& Sons, Inc. Published 2011 by John Wiley \& Sons, Inc. 


\subsection{PANDEMIC INFLUENZA}

\subsubsection{Introduction}

The World Health Organization (WHO) has recently documented that infectious diseases are not only spreading faster but emerging at an unprecedented rate of one or more per year, resulting in the addition of $\sim 40$ infectious diseases that were unknown only a generation ago (WHO, 2007). As evident from the H1N1 pandemic of 2009, we cannot be certain whether highly pathogenic avian influenza A H5N1, H9N2, or another subtype will spark a human pandemic (Wan et al., 2008), but what does appear certain is that another influenza pandemic will occur at some point in the future in the absence of a universal influenza vaccine (Cabinet Office, 2008; U.S. Homeland Security Council, 2007). In response to this pressure, many countries worldwide have published pandemic preparedness plans (European Influenza Surveillance Scheme, 2008; Mounier-Jack and Coker, 2006). The aims of these plans are to maintain essential services, reduce disease transmission, minimize the socioeconomic consequences of a pandemic, and reduce clinical cases, hospitalizations, and deaths (WHO, 2005). Key to the plans is slowing the spread of pandemic influenza through: (i) vaccine development, stockpiling, and distribution (Department of Health and Human Services and Department of Homeland Security, 2007), (ii) nonpharmaceutical measures (U.S. Centers for Disease Control and Prevention, 2007), and (iii) antiviral and antibiotic stockpiling and distribution (Hampson, 2008; NAS, 2008; U.S. Department of Health and Human Services, 2007). While the existence of prepa $\equiv$ ss plans in many countries highlights the attention that is given to the effects pandemic on society, possible implications of pharmaceutical therapies on the environment have been addressed much less. This chapter addresses how concentrations of antivirals and antibiotics occurring in wastewater treatment plants (WWTP) and surface water can be simulated, and whether these concentrations could have $\equiv$ ronmental effects or favor resistance development.

\subsubsection{Influenza-Symptoms and Treatment}

Influenza in adults is characterized by the abrupt onset of fever, myalgia, headache, malaise, nonproductive cough, sore throat, and rhinitis. Otitis media, nausea, and vomiting are the more commonly reported symptoms of influenza in children. Pronounced elevation of proinflammatory cytokines during H5N1 influenza virus infection, known as the "cytokine storm," is hypothesized to be the main cause of pathology and ultimately of death from uncomplicated influenza (Salomon et al., 2007). Although uncomplicated influenza typically resolves within 7 days, a cough and malaise can persist for $>2$ weeks. Influenza can cause viral pneumonia, exacerbate underlying medical conditions (e.g., pulmonary or cardiac disease), and lead to secondary bacterial pneumonia.

A vaccine is the first line of defense against influenza virus infections; however, its production is hampered by the inability to predict the antigentic details of the pandemic strain before it arrives. Moreover, a vaccine will only become available roughly 4-6 months after the outset of a pandemic as a result of an outdated vaccine production system (e.g., egg culture) and insufficient production capacity (WHO, 2006a). Owing to this delay, it is estimated that only $14 \%$ of the world's population 
are predicted to have available to them a vaccine for the pandemic influenza strain within the first year (Osterholm, 2005; Uscher-Pines et al., 2006). Given these uncertainties, the WHO has recommended a number of mitigating strategies to help slow the spread of the pandemic, thereby providing additional time for a vaccine to be developed, distributed, and administered. Antivirals are to play a key role in this mitigation strategy.

Treatment for influenza using antivirals must be achieved within 48 hours of the onset of symptoms. Empirical antiviral therapy will be used in the absence of rapid diagnostic tests for influenza infection (Lim, 2007; U.S. Department of Health and Human Services, 2008). Currently, licensed antivirals for therapy and/or prophylaxis of influenza fall into two classes - the adamantanes (amantadine and rimantadine), M2 ion channel inhibitors effective against influenza A viruses only, and the neuraminidase inhibitors [NAI; oseltamivir ethylester phosphate (OE-P; Tamiflu) and zanamivir (Relenza)] - that are effective against both influenza A and B viruses. Although amantadine (Symmetrel) and rimantadine (Flumadine) are approved by the U.S. Food and Drug Administration (FDA) for the treatment $\equiv$ or prevention of influenza, adamantane resistance is high and growing and $\overline{\overline{45}}$ therefore not recommended for use during an influenza pandemic (Barr et al., 2007; Jefferson, 2007). Neuraminidase inhibitors (NAI), such as Tamiflu, Relenza, and Peramivir, are sialic acid analogs that inhibit the influenza neuraminidase enzyme, which is required for the release of progeny virions from infected cells. An inhibited neuraminidase ensures that the virions remain tethered to the infected cell surface, thereby limiting viral shedding (Ong and Hayden, 2007). Neuraminidase enzyme $\mathrm{IC}_{50}$ values for oseltamivir for clinically isolated influenza A ranged from 0.1 to $1.3 \mathrm{nM}$, and for influenza B was $2.6 \mathrm{nM}$ (Roche, 2007).

The WHO has strongly recommended the use of Tamiflu (oseltamivir carboxylate; produced and distributed by Hoffmannn-La Roche) as the primary choice for combating an influenza pandemic as: (i) it is easy to administer (capsule), (ii) it is systemically active, and (iii) it is effective against characterized influenza A and B viruses (Roche Group, 2006; WHO, 2006b).

\subsubsection{Antiviral Stockpiling}

Many countries have stockpiled antivirals as part of their preparedness plans. Even before the 2009 pandemic, Roche reported orders for Tamiflu from more than 80 countries, equating to approximately 215 million treatments (Tierney and Reddy, 2007). Many countries, including the United States and the United Kingdom, are supplementing their antiviral stockpiles (Reuters, 2007) to include Relenza, (Zanamivir, marketed and distributed by GlaxoSmithKline), with the expectation of further supplementation with drugs soon to be available, such as Peramivir (marketed and distributed by BioCryst Pharmaceuticals) (Morse, 2007; Pharmaceuticals, 2007) and A-315675 (produced by Abbott Laboratories) (Kati et al., 2002), among many others in development.

\subsubsection{Secondary Bacterial Infections}

The main complication from influenza is secondary bacterial infection, particularly pneumonia (Brundage, 2006; Brundage and Shanks, 2008; Gupta et al., 2008; 
Morens et al., 2008; New England Journal of Medicine Editors, 2009; Peltola et al., 2005; Rainsford, 2006; Schwarzmann and Sullivan, 1971; UK Department of Health, 2007b). The most common bacterial etiologies for influenza-associated communityacquired pneumonia (IA-CAP) are Streptococcus pneumoniae, Haemophilus influenzae, Moraxella catarrhalis, and Staphylococcus aureus (Lim, 2007; Schwarzmann and Sullivan, 1971; Siquier et al., 2006; UK Department of Health, 2007b $\equiv$ m, 2007; Schwarzmann and Sullivan, 1971; Siquier et al., 2006; UK Department of Health, $2007 b)$. IA-CAP is characterized by fever ( $97 \%$ of cases), malaise $(80 \%)$, respiratory symptoms, for example, cough, chest pain, shortness of breath (80-85\%), headache (65\%), and others (Bannister et al., 2006; Lim, 2007; Louria et al., 1959). Mortality of viral or combined viral-bacterial pneumonia is $\sim 10-12 \%$ (Public Health Agency of Canada, 2004).

Chemotherapy guidelines for treating IA-CAP have been recently published with the backing of the British Infection Society, British Thorax Society, and the Health Protection Agency (Lim, 2007). This guidance is tailored toward pandemic IA-CAP, which distinguishes itself from previously published CAP guidelines, for example, American Thoracic Society (ATS)(ATS, 2005). Antibiotic therapy for IA-CAP will be empirical as a result of the anticipated overwhelming surge of patients during a pandemic (Gupta et al., 2008; Nap et al., 2007; UK Department of Health, 2007a).

Patients with IA-CAP infections receive antibiotic therapy and a range of overthe-counter (OTC) medications, for example antipyretics, antiphlogistics, cough medicine, and decongestants, used to relieve some of the discomfort of the illness (U.S. Department of Health and Human Services, 2005). In addition to treating the influenza virus infection, there will be considerable use of OTC drugs including analgesics and antiphlogistics. Personal stockpiles of these drugs have been recommended for all families within the U. S. Pandemic Flu Preparedness Checklist for Individuals \& Families (Meltzer et al., 1999; U.S. Department of Health and Human Services, 2006).

The availability of antibiotics within a country is considerably less defined than it is for antivirals. Recently, the UK Department of Health announced the intention to purchase 14.7 million courses of antibiotics, to cover at-risk groups totaling $25 \%$ of the population (Department of Health, 2007). However, to date, there was no indication of the nature of the stockpile. Owing to the threat of bioterrorism, many countries maintain a stockpile of antibiotics, primarily ciprofloxacin, for postexposure anthrax treatment (Gupta et al., 2008). The United States stockpiles sufficient antibiotics (ciprofloxacin and doxycycline) to treat 60 million people. Both of these antibiotics could be mobilized to treat some, but not all, of the causes of IA-CAP (Fowler et al., 2005; Gupta et al., 2008).

\subsection{EXPOSURE ASSESSMENT OF ANTIBIOTICS AND ANTIVIRALS DURING A PANDEMIC}

In order to determine risks of pandemic antiviral and antibiotic loads in the aquatic environment, knowledge on the concentrations in WWTPs and surface water as well as on possible effects on WWTP bacterial communities and occurrence of antibiotic resistance is needed. In this section, we summarize how concentrations can be predicted from coupling a spatially structured global epidemic model with a GIS- 
based watershed model. $\equiv$ pur knowledge, the modeling approaches described in (Singer et al., submitted) and in this chapter are the first investigations of possible antibiotic concentrations during an influenza pandemic.

The spatiotemporal pattern of the pandemic and its concurrent secondary infections were simulated by use of the global epidemic and mobility (GLEaM) model (Balcan et al., 2009a), which maps 6 billion individuals and integrates their mobility data. Parameters of the infection dynamics consisted of transmission of influenza under seasonal variation and included secondary infections according to the UK Pandemic Assumptions for complication, hospitalization, and intensive care unit admission rates (Balcan et al., 2009b) (UK Department of Health, 2009). In order to incorporate a wide range of possible influenza transmission potentials, we explored a mild pandemic $\left(R_{0}=1.65\right)$, a moderate $\left(R_{0}=1.9\right)$, as well as a severe $\left(R_{0}=2.3\right)$ scenario. $R_{0}$, the basic reproductive number, is the average number of secondary infections produced by a single infected individual while he or she is infectious in an entirely susceptible population. This is a measure of the degree of transmissibility of an infection (Anderson and May, 1991). No large-scale antiviral treatment was included in the mild scenario. For the other two scenarios, Tamiflu antiviral treatment was foreseen, with the assumption that $30 \%$ of the cases were detected and antiviral treated. It was assumed that antiviral treatment reduced the infectious period and the rate of development of secondary infections (Kaiser et al., 2003; Nicholson et al., 2000; Treanor et al., 2000; Whitley et al., 2001).

Within each scenario, we explored the effect of antiviral prophylaxis for 2 or 4 weeks from the start of the outbreak per country, as well as the effect of no prophylaxis. Antibiotics were assumed to be used according to guidelines for treating influenza-associated pneumonia sanctioned by the British Infection Society, British Thoracic Society, and the UK Health Protection Agency (Lim, 2007) (Table 26.1). It should be noted that this is only a small subset of the drugs that have been proposed to be used during a pandemic. Table 26.2 presents data on the environmental fate of a wide range of antibiotics that may be used during a pandemic, reflecting the considerable variation in antibiotic prescribing that exists regionally, nationally, and globally (Coenen et al., 2006; de Neeling et al., 2001; Ferech et al., 2006; García-Rey et al., 2002; Muller et al., 2007; Priest et al., 2001); and the possibility that, dependent on the extent of any stockpile, shortages are likely to occur and a range of antibiotics might be used (Gupta et al., 2008). Table 26.3 summarizes data on concentrations in WWTPs and surface water for pharmaceuticals that have been proposed for use during an influenza pandemic.

Simulations of an influenza pandemic $\left(R_{0}\right)$ resulted in estimates of the cases of influenza and pneumonia at each stage of disease progression, together with the quantities of drugs used. Simulations were able to project cases and drugs down to the spatial resolution scale of $1 / 4^{\circ}$ and a time resolution of one day. A water quality model, Low Flows 2000-Water Quality Extension (LF2000-WQX) (Rowney et al., 2009), then predicted the environmental release of antivirals and antibiotics. Values for excretion of active substances within the feces and/or urine were taken from the literature (see Table 26.4). Dilution processes in the river were modeled using the annual mean flow from each river stretch, while a worst-case scenario of no pharmaceutical degradation or loss to sorption in WWTPs and rivers was applied (see Fig. 26.1). The Thames catchment in the southern United Kingdom was chosen as a model test case. 
TABLE 26.1 Preferred and Alternative Empirical Antibiotic Treatment Regimens for Pneumonic Influenza-Associated Complications

\begin{tabular}{|c|c|c|c|c|}
\hline $\begin{array}{l}\text { CURB- } \\
65 \text { Score }\end{array}$ & Compartment & $\begin{array}{l}\text { Preferred Treatment } \\
\text { Regimen }\end{array}$ & Alternative Treatment Regimen & Duration \\
\hline 0-2 & $P^{I}, P^{I I}$ & $\begin{array}{l}\text { Co-amoxiclav } 625 \mathrm{mg} \\
\text { tds PO } \\
\text { or } \\
\text { doxycycline } 200 \mathrm{mg} \\
\text { stat and } 100 \mathrm{mg} \text { od } \\
\text { PO }\end{array}$ & $\begin{array}{l}\text { Macrolide } \\
\text { (erythromycin } 500 \mathrm{mg} \text { qds PO } \\
\text { or clarithromycin } 500 \mathrm{mg} \text { bd } \\
\text { PO) } \\
\text { or } \\
\text { fluoroquinolone } \\
\text { (e.g., levofloxacin } 500 \mathrm{mg} \\
\text { od PO or moxifloxacin } 400 \mathrm{mg} \\
\text { od PO) }\end{array}$ & 7 days \\
\hline $3-5$ & $P^{I I I}$ & $\begin{array}{l}\text { Co-amoxiclav } 1.2 \mathrm{~g} \text { tds } \\
\text { IV } \\
\text { or } \\
\text { cefuroxime } 1.5 \mathrm{~g} \text { tds IV } \\
\text { or } \\
\text { cefotaxime } 1 \mathrm{~g} \text { tds IV } \\
\text { plus } \\
\text { macrolide } \\
\text { (erythromycin } 500 \mathrm{mg} \\
\text { qds IV or } \\
\text { clarithromycin } 500 \mathrm{mg} \\
\text { bd IV) }\end{array}$ & $\begin{array}{l}\text { Fluoroquinolone with some } \\
\text { enhanced pneumococcal } \\
\text { activity (e.g., levofloxacin } 500 \\
\text { mg od IV or moxifloxacin } 400 \\
\text { mg od PO) } \\
\text { plus, either } \\
\text { macrolide } \\
\text { (erythromycin } 500 \mathrm{mg} \text { qds IV } \\
\text { or clarithromycin } 500 \mathrm{mg} \text { bd } \\
\text { IV) } \\
\text { or } \beta \text {-lactamase stable } \\
\text { antibiotic (i.e., co-amoxiclav } \\
1.2 \text { g tds IV or cefuroxime } \\
1.5 \text { g tds IV or cefotaxime } 1 \mathrm{~g} \\
\text { tds IV) }\end{array}$ & 10 days \\
\hline
\end{tabular}

Source: From Lim (2007).

A survey of the literature as well as an examination of the STPWIN model (U.S. Environmental Protection Agency, 2007) within the Estimation Program Interface (EPI) SuiteTM 4.0 indicates low $(<20 \%)$ removal for most antibiotics in WWTPs, inclusive of loss due to sorption and biodegradation (Fig. 26.1). A literature search revealed that most antibiotics, particularly those not containing a $\beta$-lactam moiety, are resistant to metabolism in vivo as well as in the environment (Al-Ahmad et al., 1999; Alexy et al., 2004; Benotti and Brownawell, 2009; Brain et al., 2004a; 2004b; Gartiser et al., 2007; Junker et al., 2006; Kümmerer et al., 2000), with half-lives of days to weeks (Benotti and Brownawell, 2009; Christensen, 1998). For these reasons, we feel there was justification in assuming a conservative pharmaceutical biodegradation model of zero degradation/sorption.

\subsubsection{Interpandemic Antibiotic and Antiviral Use}

A very wide range of pharmaceuticals are in constant use in a population and thus will be present in the wastewater during a pandemic (Kümmerer, 2009a, 2009b). While the relative contribution of single antibiotic classes to overall use does not greatly vary between countries (Fig. 26.2), the absolute amount of defined daily 


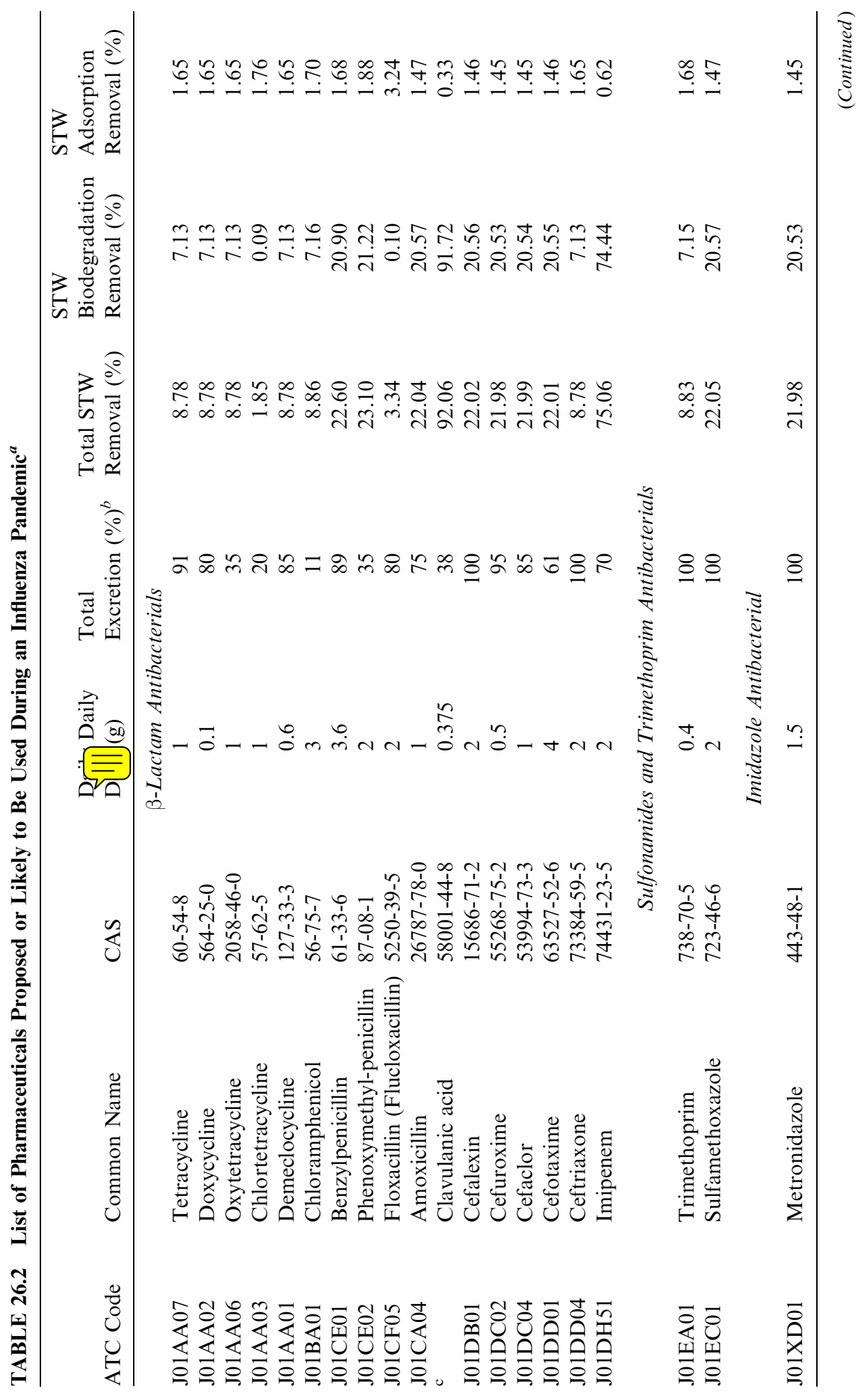




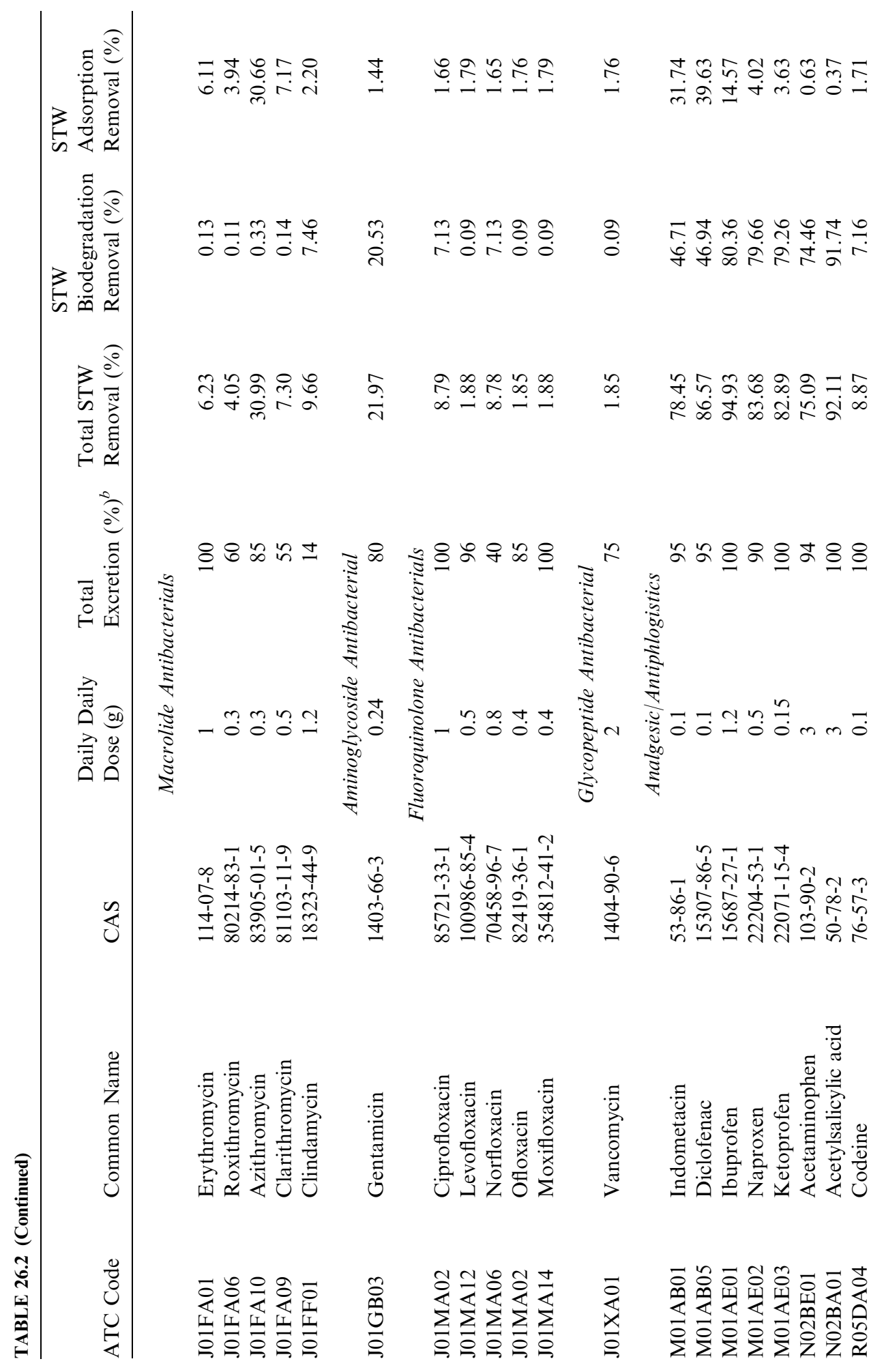




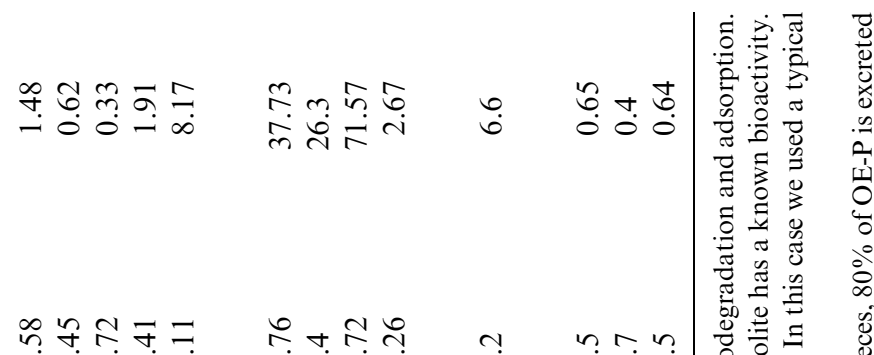

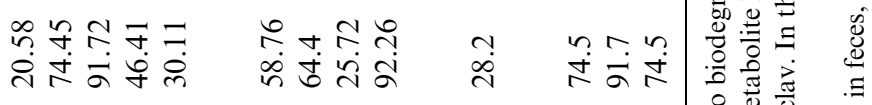

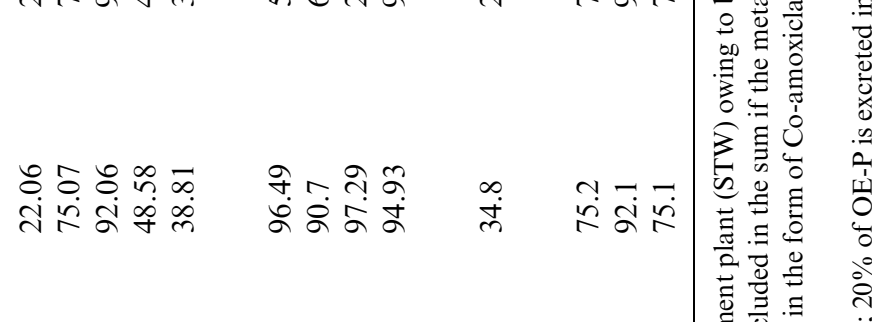

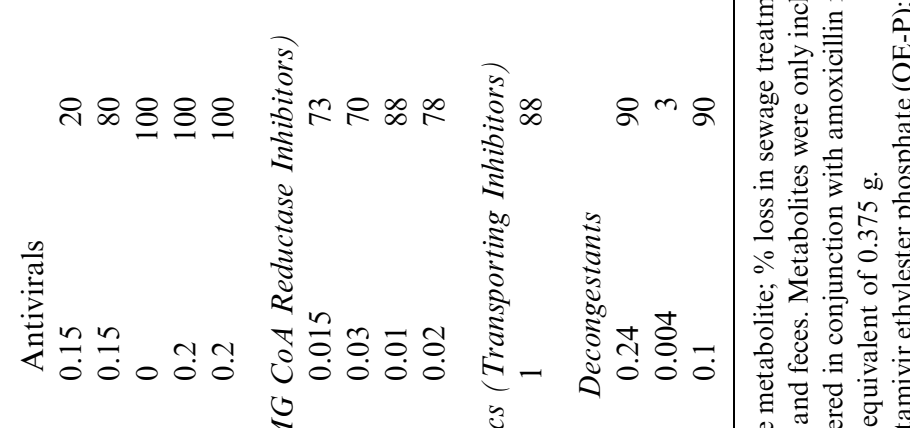

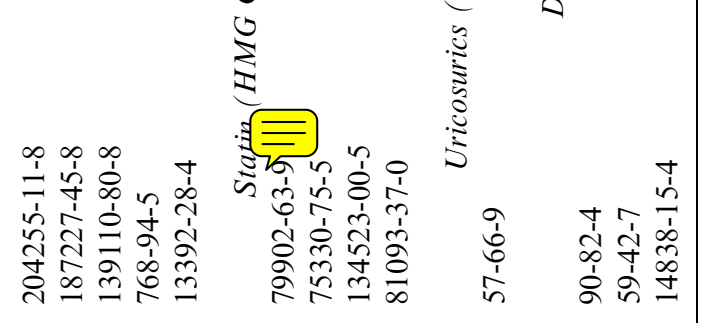

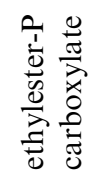

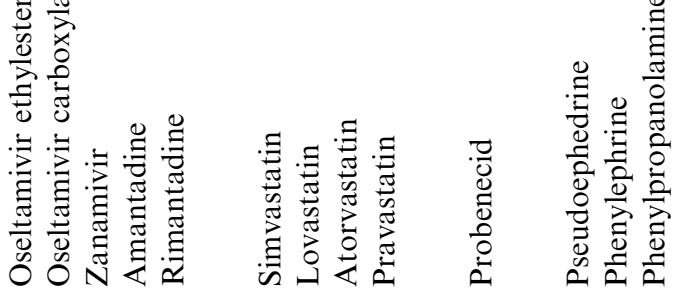
管

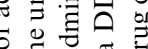
妾. 함

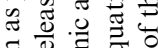
흔 흥

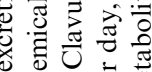

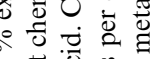

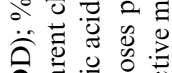
人ิ C을

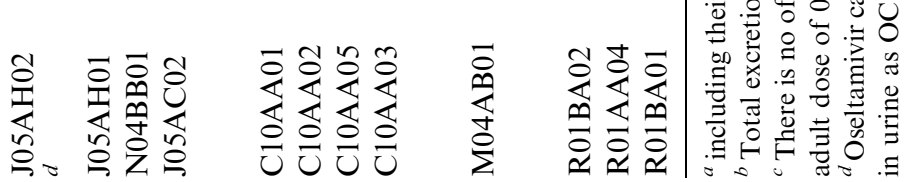




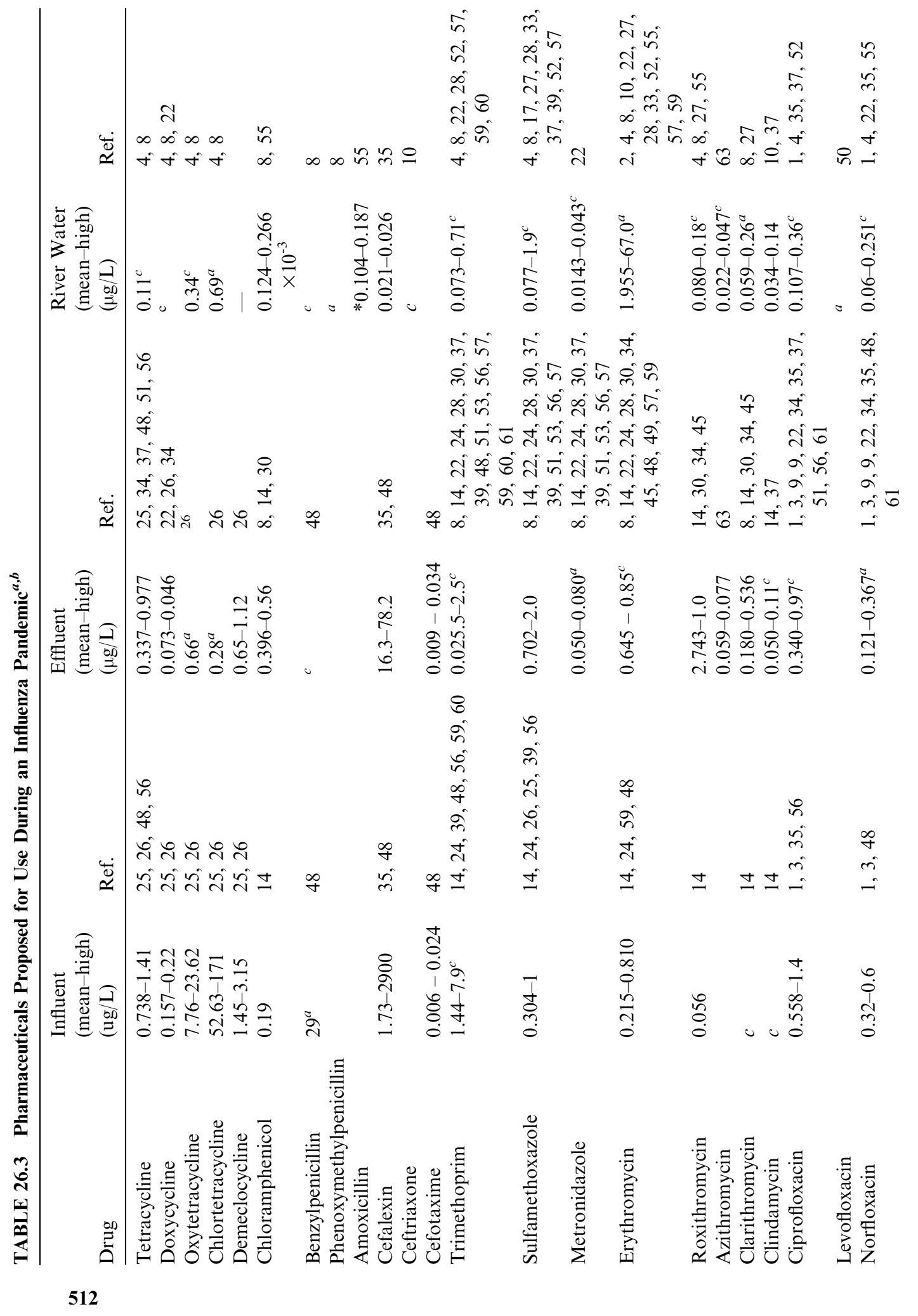




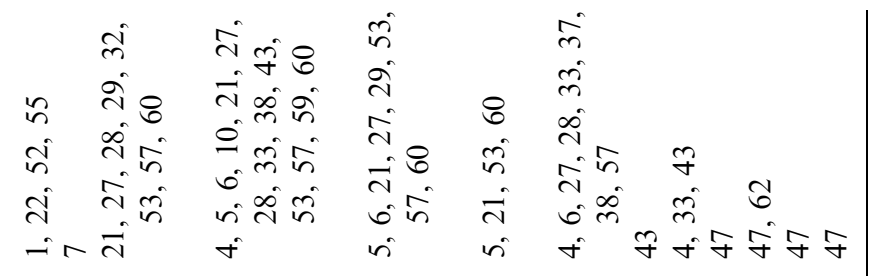

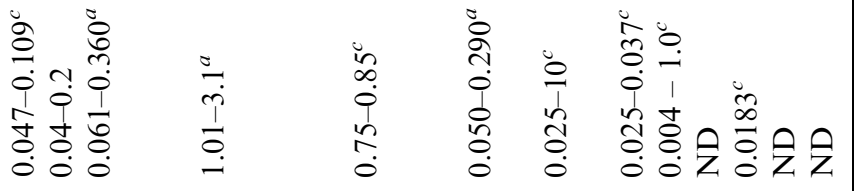

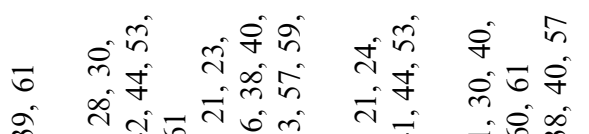

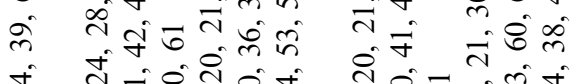

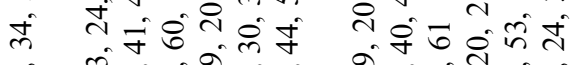

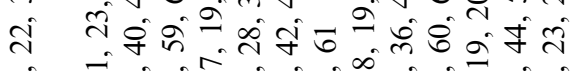

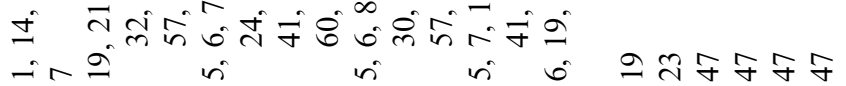

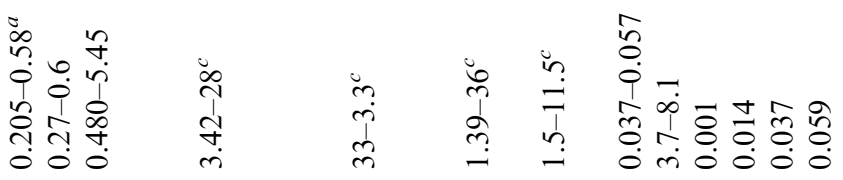

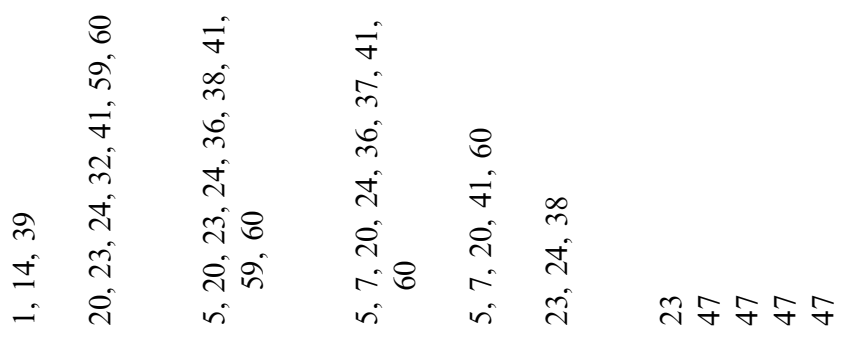

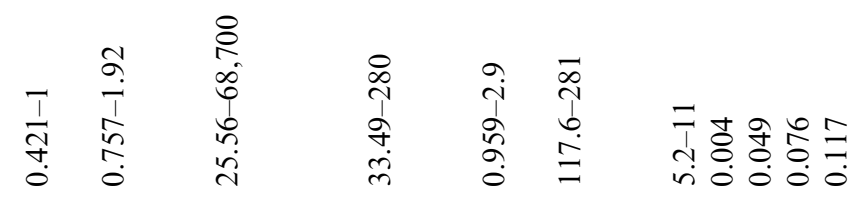
II

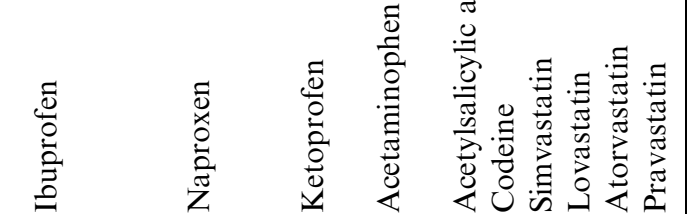

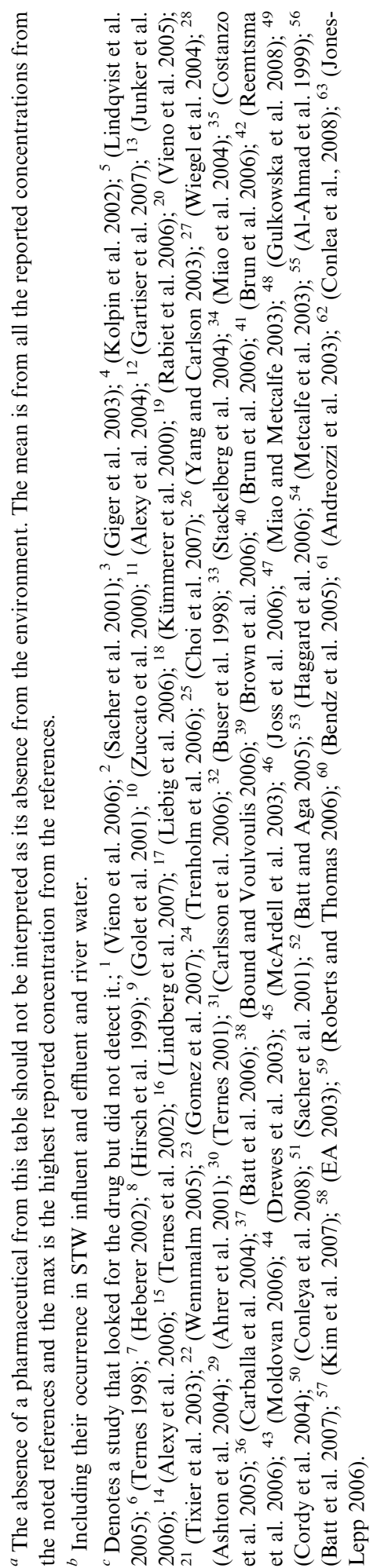

513 
TABLE 26.4 Percentage of Parent Pharmaceuticals Investigated in This Study Excreted in the Feces and Urine unchanged and/or as a Bioactive Metabolite

\begin{tabular}{lc}
\hline Pharmaceutical & $\begin{array}{c}\text { \% Excreted as Parent or } \\
\text { Bioactive Metabolite }\end{array}$ \\
\hline Tamiflu & 100 \\
Amoxicillin & 75 \\
Clavulanate & 38 \\
Doxycycline & 80 \\
Cefuroxime & 95 \\
Cefotaxime & 61 \\
Erythromycin & 100 \\
Clarithromycin & 55 \\
Levofloxacin & 96 \\
Moxifloxacin & 100 \\
\hline
\end{tabular}

Source: From Dollery (1999) and Wishart et al. (2006).

dosages per 1000 inhabitants per day ranges between 10 and $>20$ in Europe (Coenen et al., 2006; Ferech et al., 2006; Muller et al., 2007). If one was to use the average annual antibiotic usage within England during an interpandemic period (NHS BSA, 2008) as a first approximation, $62 \mu \mathrm{g}$ antibiotics/L would be present in the UK WWTPs, which was assumed to be di $\equiv$ by the median volume of wastewater in WWTP within the Thames catchment are a, $230 \mathrm{~L} /$ head/day (Table 26.5).

Table 26.3 and Figure 26.3 give an extensive overview on the concentrations of antibiotics that have been found in WWTP and surface water globally as well as in the United Kingdom. When comparing predicted and actual concentrations of antibiotics in WWTPs (Table 26.5 vs Table 26.3), it should be noted that veterinary use significantly contributes to concentrations in surface water (Hurd and Raef, 2010; Smith et al., 2002) such that WWTP effluent is not the only source of antibiotic residues in the aquatic environment. Over-and underestimations of predicted concentrations of antibiotics in the environment can also be caused by unforeseen losses from sorption and/or degradation, the impact of climate on degradation, difference in antibiotic use between different regions within a country, as well as countryspecific differences, seasonal fluctuations in drug use, as well as seasonal fluctuations on WWTPs and river dilution (ter Laak et al., 2010). Hence, it is very difficult to project the concentration of antibiotics in use during interpandemic periods for any one location at any particular time. For this study we employed annual usage statistics for England (2007) with no further modification or adjustment.

Unlike antibiotics, interpandemic usage of Tamiflu in the United Kingdom been reported to be r $\equiv$ ible (Kramarz et al., 2009), implying that any substantial increase will be as result of the influenza pandemic.

\subsubsection{Projected Concentrations of Antibiotics and Tamiflu in WWTP and Rivers During a Pandemic}

In WWTPs, a mild pandemic scenario was projected to increase interpandemic antibiotic use of the same antibiotics (see Section ) by only approximately $1 \%$ (95\% 


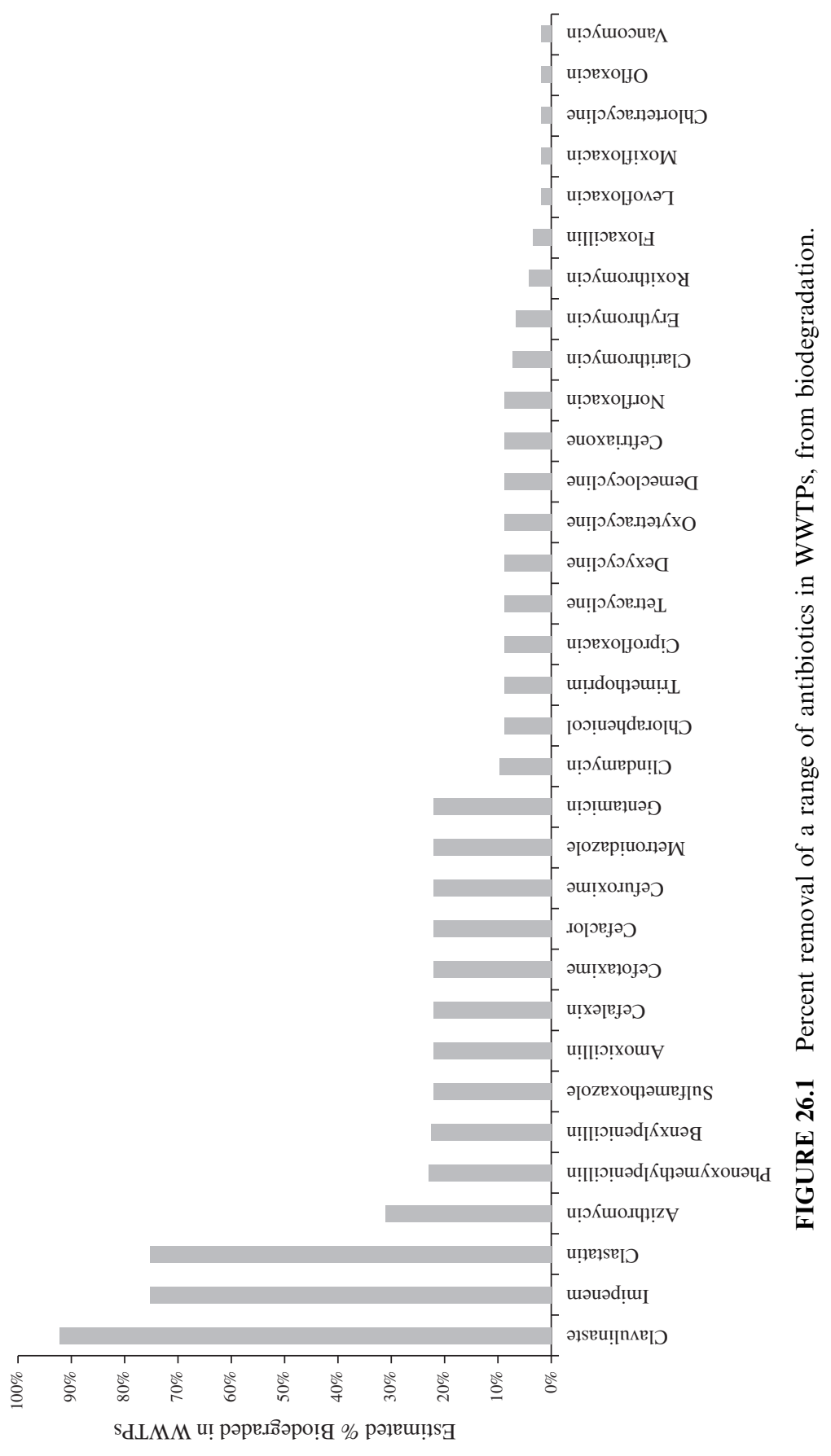



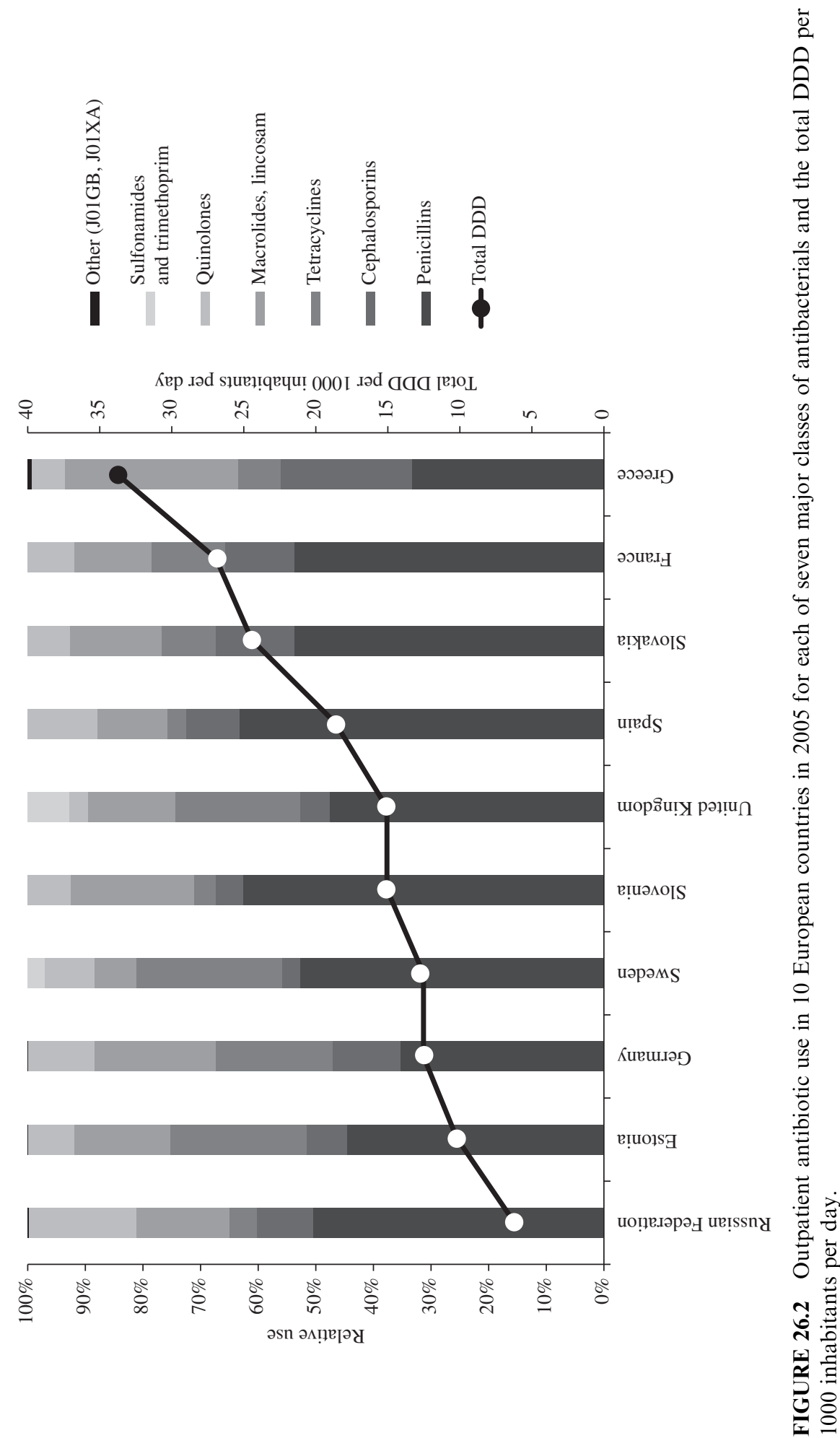
TABLE 26.5 $\equiv$ ated Concentration of Antibiotics in English WWTP During an Interpandemic period ${ }^{a}$

\begin{tabular}{|c|c|c|c|}
\hline & $\begin{array}{l}\text { Combined } \\
\mu \mathrm{g} / \text { head/d }\end{array}$ & $\begin{array}{l}\% \text { of Total } \\
\text { Antibiotics in Use } \\
\text { (mass basis) }\end{array}$ & $\begin{array}{l}\text { Estimated } \\
\text { Concentration in } \\
\text { WWTP }(\mu \mathrm{g} / \mathrm{L})\end{array}$ \\
\hline Floxacillin + co-fluampicil & 4068 & 28.0 & 17.5 \\
\hline $\begin{array}{l}\text { Amoxicillin + co- } \\
\text { amoxiclav }\end{array}$ & 3698 & 25.4 & 15.9 \\
\hline Cefalexin & 2023 & 13.9 & 8.68 \\
\hline Erythromycin & 1391 & 9.6 & 5.97 \\
\hline Ampicillin & 840 & 5.8 & 3.61 \\
\hline Ciprofloxacin & 582 & 4.0 & 2.50 \\
\hline Penicillin V & 531 & 3.6 & 2.28 \\
\hline Trimethoprim & 387 & 2.7 & 1.66 \\
\hline Cefradine & 253 & 1.7 & 1.09 \\
\hline Clarithromycin & 156 & 1.1 & 0.671 \\
\hline Cefaclor & 129 & 0.9 & 0.553 \\
\hline Cefadroxil & 126 & 0.9 & 0.543 \\
\hline Clavulanate & 108 & 0.7 & 0.464 \\
\hline Oxytetracycline & 66 & 0.5 & 0.285 \\
\hline Lymecycline & 47 & 0.3 & 0.202 \\
\hline Sulfamethoxazole & 36 & 0.3 & 0.156 \\
\hline Cefuroxime & 24 & 0.2 & 0.103 \\
\hline Minocycline & 30 & 0.2 & 0.128 \\
\hline Doxycycline & 12 & 0.1 & 0.052 \\
\hline Azithromycin & 16 & 0.1 & 0.069 \\
\hline Ofloxacin & 9 & 0.1 & 0.041 \\
\hline Norfloxacin & 8 & 0.1 & 0.035 \\
\hline Levofloxacin & 7 & 0.1 & 0.031 \\
\hline Moxifloxacin & 5 & $<0.1$ & 0.022 \\
\hline
\end{tabular}

${ }^{a}$ Drug use was as reported by the National Health Service Business Services Authority (NHS BSA, 2008). Where the ADQ (average daily quantity) was unknown, the DDD (defined daily dose) (World Health Organization, 2004) was used to calculate the mass of drug used per head per day (population of England served by the NHS: $54,180,000$ ).

reference range, RR, of the stochastic epidemic model: $0.4-23 \%)$. An increase by $13 \%(95 \% \mathrm{RR}, 1-83 \%)$ and $252 \%(95 \% \mathrm{RR}, 158-279 \%)$ was determined for the moderate and severe scenarios. In absolute concentrations, a moderate pandemic would increase interpandemic concentrations by $1.2-3 \mu \mathrm{g} / \mathrm{L}$ (total of all antibiotics; mean concentration of all 135 WWTP in the Thames catchment area for the median epidemic scenario, Table 26.6). A severe pandemic would cause total antibiotic concentrations to reach $55-60 \mu \mathrm{g} / \mathrm{L}$ on average, with a maximum of $800 \mu \mathrm{g} / \mathrm{L}$ for the WWTP with the lowest dilution. Amoxicillin and erythromycin have the greatest share of the total antibiotic load (59 and $18 \%$, respectively). Tamiflu concentrations greatly vary with the epidemic scenario for mild and moderate $R_{0}$ and are highest if antiviral prophylaxis is assumed for $10 \%$ of the population (around $45 \mu \mathrm{g} / \mathrm{L}$ in the mild and moderate scenario). A severe pandemic would increase Tamiflu concentrations to $>80 \mu \mathrm{g} / \mathrm{L}$ on average (Table 26.6). 


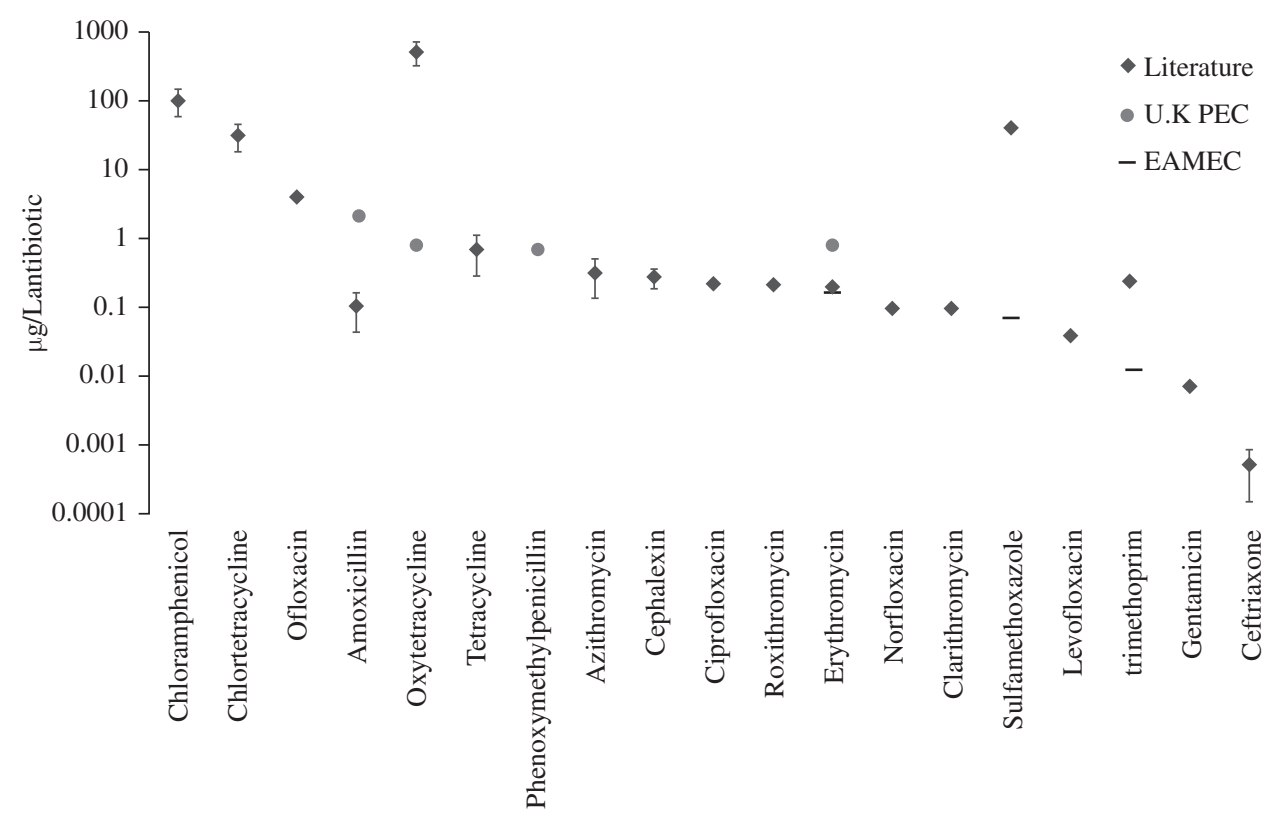

FIGURE 26.3 Prepandemic river water concentration of pharmaceuticals that have been examined in STW effluent and/or river water.

Mean concentrations of total antibiotics in the Thames catchment were projected to be $<0.09$ and $<0.8 \mu \mathrm{g} / \mathrm{L}$ for a mild and moderate pandemic, respectively (Table 26.7). On the other hand, a severe pandemic was projected to achieve $<15 \mu \mathrm{g} / \mathrm{L}$ total antibiotics, with a maximum of $80 \mu \mathrm{g} / \mathrm{L}$. A mild and moderate pandemic with AVP $>0$ was projected to generate mean concentrations of Tamiflu in the Thames catchment between 1.1 and $11.5 \mu \mathrm{g} / \mathrm{L}$ (Table 26.7). A more severe pandemic, regardless of AVP, was projected to result in mean concentrations of Tamiflu in the Thames catchment in excess of $100 \mu \mathrm{g} / \mathrm{L}$, consistent with previous projections of a severe pandemic in southern England (Singer et al., 2007).

\subsection{EFFECTS ASSESSMENT OF ANTIBIOTICS DURING A PANDEMIC}

Elevated concentrations of antibiotics during a pandemic will, in the first instance, affect microbial consortia in WWTPs and surface waters. In order to evaluate such potential effects of antibiotics, we determined the fraction of bacteria that were potentially affected by a given antibiotic exposure [(potentially affected fraction, PAF). This approach projects effects on whole communities from toxicities of a substance to single members of the community compiled in species-sensitivity distributions (SSD) (Newman et al., 2002)]. As experimental data on the toxicity of the chosen antibiotics is almost entirely lacking, we based our analyses on minimum inhibitory concentrations (MIC) of human pathogens from the EUCAST database (EUCAST, 2009). Through the application of models for mixture toxicity (De Zwart and Posthuma, 2005), we accounted for the presence of all eight antibiotics simultaneously (clavulanate was omitted because no MICs were present for this 
TABLE 26.6 Projected Mean Concentrations of Antibiotics and Tamiflu in WWTP in the Thames Basin ${ }^{a}$

\begin{tabular}{|c|c|c|c|c|}
\hline \multirow[b]{2}{*}{ Scenario $^{b}$} & \multicolumn{2}{|c|}{ Antibiotics $(\mu \mathrm{g} / \mathrm{L})$} & \multicolumn{2}{|c|}{ Tamiflu $(\mu \mathrm{g} / \mathrm{L})$} \\
\hline & Mean \pm Stdev & Maximum & Mean \pm Stdev & Maximum \\
\hline \multicolumn{5}{|l|}{$R_{0} 1.65$} \\
\hline s1 & $0.36 \pm 0.4$ & 4.76 & $0.78 \pm 0.87$ & 10.41 \\
\hline $\mathrm{s} 2$ & $0.34 \pm 0.37$ & 4.49 & $4.63 \pm 5.14$ & 61.55 \\
\hline s3 & $0.34 \pm 0.37$ & 4.46 & $4.86 \pm 5.4$ & 64.65 \\
\hline s4 & $0.3 \pm 0.33$ & 3.97 & $45.35 \pm 50.37$ & 603.42 \\
\hline s5 & $0.29 \pm 0.32$ & 3.83 & $45.43 \pm 50.46$ & 604.4 \\
\hline s6 & $0.05 \pm 0.06$ & 0.73 & $0.11 \pm 0.12$ & 1.49 \\
\hline \multicolumn{5}{|l|}{$R_{0} 1.9$} \\
\hline s1 & $2.99 \pm 3.32$ & 39.8 & $4.02 \pm 4.46$ & 53.44 \\
\hline s2 & $2.85 \pm 3.17$ & 38 & $4.79 \pm 5.32$ & 63.67 \\
\hline s3 & $2.97 \pm 3.3$ & 39.5 & $6.05 \pm 6.72$ & 80.53 \\
\hline s4 & $2.27 \pm 2.52$ & 30.2 & $45.3 \pm 50.4$ & 603.3 \\
\hline s5 & $1.71 \pm 1.9$ & 22.8 & $47 \pm 52.3$ & 625.9 \\
\hline s6 & $1.2 \pm 1.33$ & 15.9 & $1.52 \pm 1.69$ & 20.22 \\
\hline \multicolumn{5}{|l|}{$R_{0} 2.1$} \\
\hline $\mathrm{s} 1$ & $60.2 \pm 66.8$ & 800.6 & $87.9 \pm 97.6$ & 1169.5 \\
\hline $\mathrm{s} 2$ & $59.7 \pm 66.3$ & 793.6 & $87.8 \pm 97.5$ & 1167.6 \\
\hline s3 & $59.3 \pm 65.9$ & 789.6 & $87.6 \pm 97.3$ & 1166.1 \\
\hline s4 & $57 \pm 63.3$ & 757.8 & $85.5 \pm 94.9$ & 1137.2 \\
\hline s5 & $53.7 \pm 59.6$ & 714 & $80.1 \pm 89$ & 1065.6 \\
\hline s6 & $54.2 \pm 60.2$ & 721.3 & $80.7 \pm 89.6$ & 1073.6 \\
\hline
\end{tabular}

${ }^{a}$ Mean values are inclusive of all excreted antibiotics. Values reflect the median epidemic scenario for each condition and reflect the mean concentration for all 461 river stretches utilized within LF2000-WQX of parent pharmaceuticals investigated in this study excreted in the feces and urine unchanged and/or as a bioactive metabolite.

${ }^{b} \mathrm{~s} 1=$ where $\mathrm{AVP}=0$, rate of $\mathrm{AVT}=30 \%$, limited supply of Tamiflu.

$\mathrm{s} 2=$ where 2 wk AVP, AVP $=1 \%$, rate of $\mathrm{AVT}=30 \%$, limited supply of Tamiflu.

$\mathrm{s} 3=$ where $4 \mathrm{wk} \mathrm{AVP}, \mathrm{AVP}=1 \%$, rate of $\mathrm{AVT}=30 \%$, limited supply of Tamiflu.

$\mathrm{s} 4=$ where $2 \mathrm{wk}$ AVP, AVP $=10 \%$, rate of AVT $=30 \%$, limited supply of Tamiflu.

$\mathrm{s} 5=$ where $4 \mathrm{wk}$ AVP, AVP $=10 \%$, rate of AVT $=30 \%$, limited supply of Tamiflu.

$\mathrm{s} 6=$ where $\mathrm{AVP}=0$, rate of $\mathrm{AVT}=30 \%$, unlimited supply of Tamiflu.

substance on its own). Toxicities were determined for WWTP and river stretches in the Thames catchment area from antibiotic concentrations predicted through exposure modeling. The results of this determination of the potentially affected fraction of bacteria in the community based on simulated antibiotic concentrations are shown in Figures 26.4 and 26.5. For a mild pandemic, projected toxicity in WWTP was well below $1 \%$ PAF (less than $1 \%$ of the community might be growth inhibited, Fig. 26.4a). During a moderate pandemic, toxicities $>5 \%$ were predicted in $74 \%$ of the WWTP for concentrations at the upper bound of the $95 \% \mathrm{RR}$ of the stochastic model, while no toxicity was predicted for the lower bound (Fig. 26.4a). A proportion of growth-inhibited species $>5 \%$ was chosen as a pragmatic threshold for possible effects on community functioning (European Chemicals Agency, 2008). The severe pandemic was projected to affect between 8 and $32 \%$ of the microbial species in WWTP (Figs. 26.4b and 26.5c). 
TABLE 26.7 Projected Mean Concentrations of Antibiotics and Tamiflu in Rivers in the Thames Basin ${ }^{a}$

\begin{tabular}{|c|c|c|c|c|}
\hline \multirow{2}{*}{ Scenario $^{b}$} & \multicolumn{2}{|c|}{ Antibiotics $(\mu \mathrm{g} / \mathrm{L})$} & \multicolumn{2}{|c|}{ Tamiflu $(\mu \mathrm{g} / \mathrm{L})$} \\
\hline & Mean \pm Stdev & Maximum & Mean \pm Stdev & Maximum \\
\hline \multicolumn{5}{|l|}{$R_{0} 1.65$} \\
\hline s1 & $0.085 \pm 0.088$ & 0.476 & $0.186 \pm 0.192$ & 1.04 \\
\hline $\mathrm{s} 2$ & $0.082 \pm 0.084$ & 0.445 & $1.12 \pm 1.15$ & 6.09 \\
\hline s3 & $0.083 \pm 0.084$ & 0.447 & $1.20 \pm 1.21$ & 6.47 \\
\hline s4 & $0.073 \pm 0.074$ & 0.400 & $11.1 \pm 11.2$ & 60.8 \\
\hline s5 & $0.070 \pm 0.072$ & 0.384 & $11.1 \pm 11.3$ & 60.6 \\
\hline s6 & $0.013 \pm 0.014$ & 0.073 & $0.027 \pm 0.027$ & 0.149 \\
\hline \multicolumn{5}{|l|}{$R_{0} 1.9$} \\
\hline s1 & $0.741 \pm 0.744$ & 3.95 & $1.00 \pm 1.00$ & 5.31 \\
\hline s2 & $0.690 \pm 0.706$ & 3.77 & $1.16 \pm 1.19$ & 6.33 \\
\hline s3 & $0.719 \pm 0.731$ & 3.90 & $1.47 \pm 1.49$ & 7.96 \\
\hline s4 & $0.552 \pm 0.563$ & 3.01 & $11.0 \pm 11.2$ & 60.0 \\
\hline s5 & $0.418 \pm 0.427$ & 2.27 & $11.5 \pm 11.7$ & 62.4 \\
\hline s6 & $0.294 \pm 0.298$ & 1.59 & $0.37 \pm 0.38$ & 2.02 \\
\hline \multicolumn{5}{|l|}{$R_{0} 2.1$} \\
\hline $\mathrm{s} 1$ & $14.8 \pm 15.0$ & 80.5 & $21.3 \pm 21.3$ & 102 \\
\hline $\mathrm{s} 2$ & $14.5 \pm 14.8$ & 80.6 & $21.0 \pm 21.3$ & 103 \\
\hline s3 & $14.5 \pm 14.8$ & 79.9 & $21.1 \pm 21.2$ & 102 \\
\hline s4 & $14.0 \pm 14.2$ & 75.9 & $20.7 \pm 20.8$ & 99.1 \\
\hline s5 & $13.1 \pm 13.3$ & 69.3 & $19.6 \pm 19.9$ & 103 \\
\hline s6 & $13.2 \pm 13.4$ & 72.3 & $19.6 \pm 20.0$ & 108 \\
\hline
\end{tabular}

${ }^{\mathrm{a}}$ Mean values are inclusive of all excreted antibiotics. Values reflect the median epidemic scenario for each condition and reflect the mean concentration for all 461 river stretches utilized within LF2000-WQX of parent pharmaceuticals investigated in this study excreted in the feces and urine unchanged and/or as a bioactive metabolite.

${ }^{b} \mathrm{~s} 1=$ where $\mathrm{AVP}=0$, rate of AVT $=30 \%$, limited supply of Tamiflu.

$\mathrm{s} 2=$ where $2 \mathrm{wk} \mathrm{AVP}, \mathrm{AVP}=1 \%$, rate of $\mathrm{AVT}=30 \%$, limited supply of Tamiflu.

$\mathrm{s} 3=$ where 4 wk AVP, $\mathrm{AVP}=1 \%$, rate of $\mathrm{AVT}=30 \%$, limited supply of Tamiflu.

$\mathrm{s} 4=$ where $2 \mathrm{wk}$ AVP, AVP $=10 \%$, rate of AVT $=30 \%$, limited supply of Tamiflu.

$\mathrm{s} 5=$ where $4 \mathrm{wk}$ AVP, $\mathrm{AVP}=10 \%$, rate of $\mathrm{AVT}=30 \%$, limited supply of Tamiflu.

$\mathrm{s} 6=$ where $\mathrm{AVP}=0$, rate of $\mathrm{AVT}=30 \%$, unlimited supply of Tamiflu.

Absolute toxicity in rivers was projected to be slightly lower than in WWTPs, with the maximum PAF for any river stretch in a moderate pandemic being $\sim 15 \%$ (Fig. $26.4 \mathrm{e}$ ). During a severe pandemic, the $5 \%$ threshold of toxicity would be exceeded in about half of the river stretches at the upper bound of the $95 \% R$ (Fig. 26.4c), corresponding to about one third of total river length (Figs. 26.4d and 26.5f). Maximum toxicity during a severe pandemic was simulated to reach $30 \%$ (Fig. 26.4e).

The same effect models, when applied to the background concentrations of the eight investigated antibiotics, yield toxicities (PAF) in Thames catchment WWTP of between 4 and $17 \%$. At these concentrations, however, no major functional breakdowns have been recorded. Reasons for the tolerance of WWTP communities to chronic exposure to antibiotics might be: (1) reduction of bioavailable concentrations through degradation or sorption, (2) acquired community tolerance through 

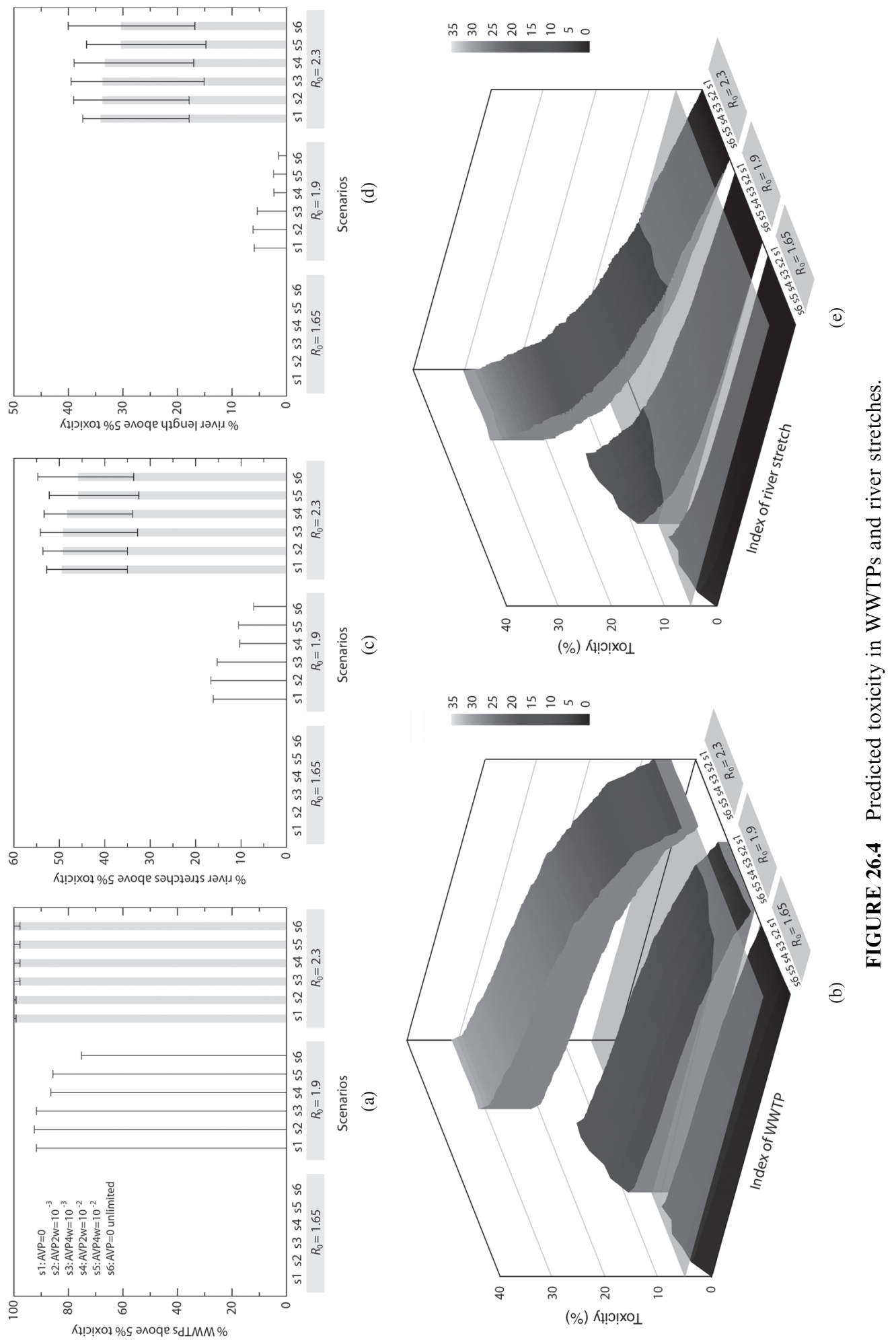

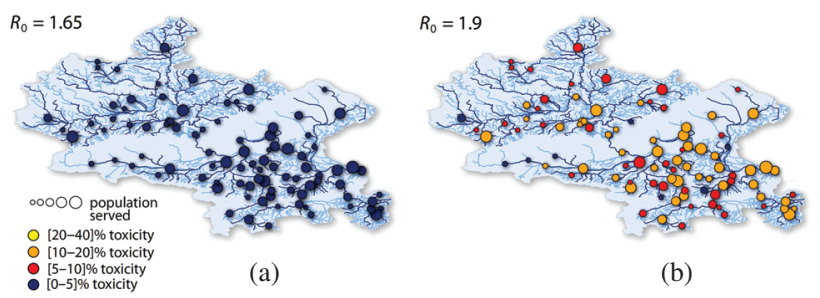

(b)
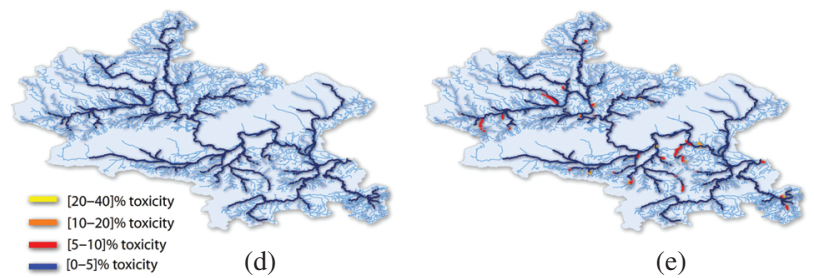

(e)

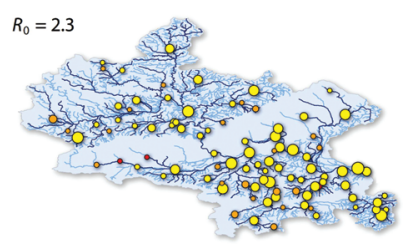

(c)

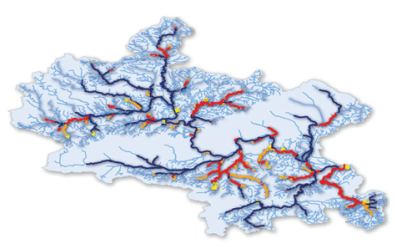

(f)

FIGURE 26.5 Predicted toxicity maps.

selection for more tolerant or resistant bacteria, (3) differences between the antibiotic sensitivity of human pathogens and WWTP bacteria, and (4) overcapacity of WWTPs, thereby enabling some decline in function to occur with no significant loss in overall sewage treatment. As only the severe scenario increases the PAF substantially, we conclude that a mild or moderate pandemic would not be likely to affect WWTP consortia.

Notably, effects modeling in this study were based on MICs of human pathogens instead of effects observed in WWTP toxicity testing. Arguably, the toxicity of antibiotics to functionally active WWTP bacteria might differ from pathogen MICs. Also, the predominance of biofilms in WWTPs as flocs will influence antibiotic toxicity. There is little experimental data to verify whether modeled toxicity matches experimental data. Also, often, studies are based on test systems that differ from a full-scale WWTP, such as through the use of batch studies or through the use of synthetic sewage as medium.

Erythromycin is the only antibiotic investigated in this study for which substantial data on toxicity in WWTPs exists. For example, in batch studies with activated sludge inoculum from French WWTPs (Louvet et al., 2010a) and raw wastewater as medium, a range of effects of erythromycin were observed. After exposure to the antibiotic for less than one hour, direct toxicity was seen in cell staining experiments. In 24-hour batch experiments with inocula collected at nine different time points, 10 $\mathrm{mg} / \mathrm{L}$ erythromycin (equivalent to a PAF of $80 \%$ according to our models) inhibited COD (chemical oxygen demand) removal by $79 \%$ on average. Inhibition strongly varied between different inocula, highlighting the dependence of batch toxicity studies on the initial inoculum. Inhibition of nitrification was $40 \%$ on average in similar experiments.

Inhibition was also found at lower concentrations of erythromycin (see Table 26.8). Further, erythromycin interfered with floc structure: flocs divided and biomass was transferred to the foam layer on top of the batch reactors (Louvet et al., 2010a). At longer exposure times of batch reactors (5 days), effects on soluble COD were observed at erythromycin concentrations as low as $4 \mu \mathrm{g} / \mathrm{L}$ (Louvet et al., 2010b), 


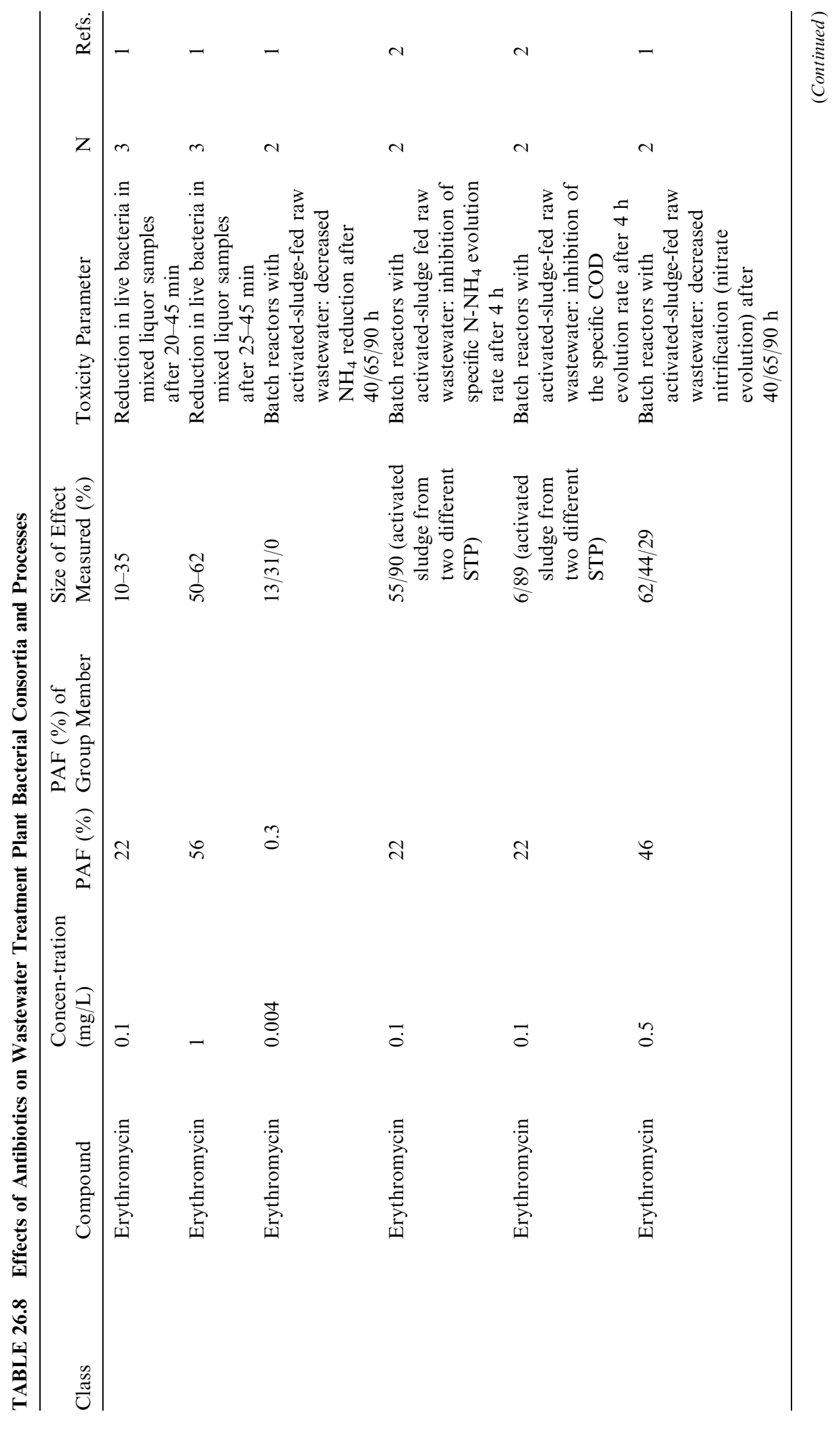




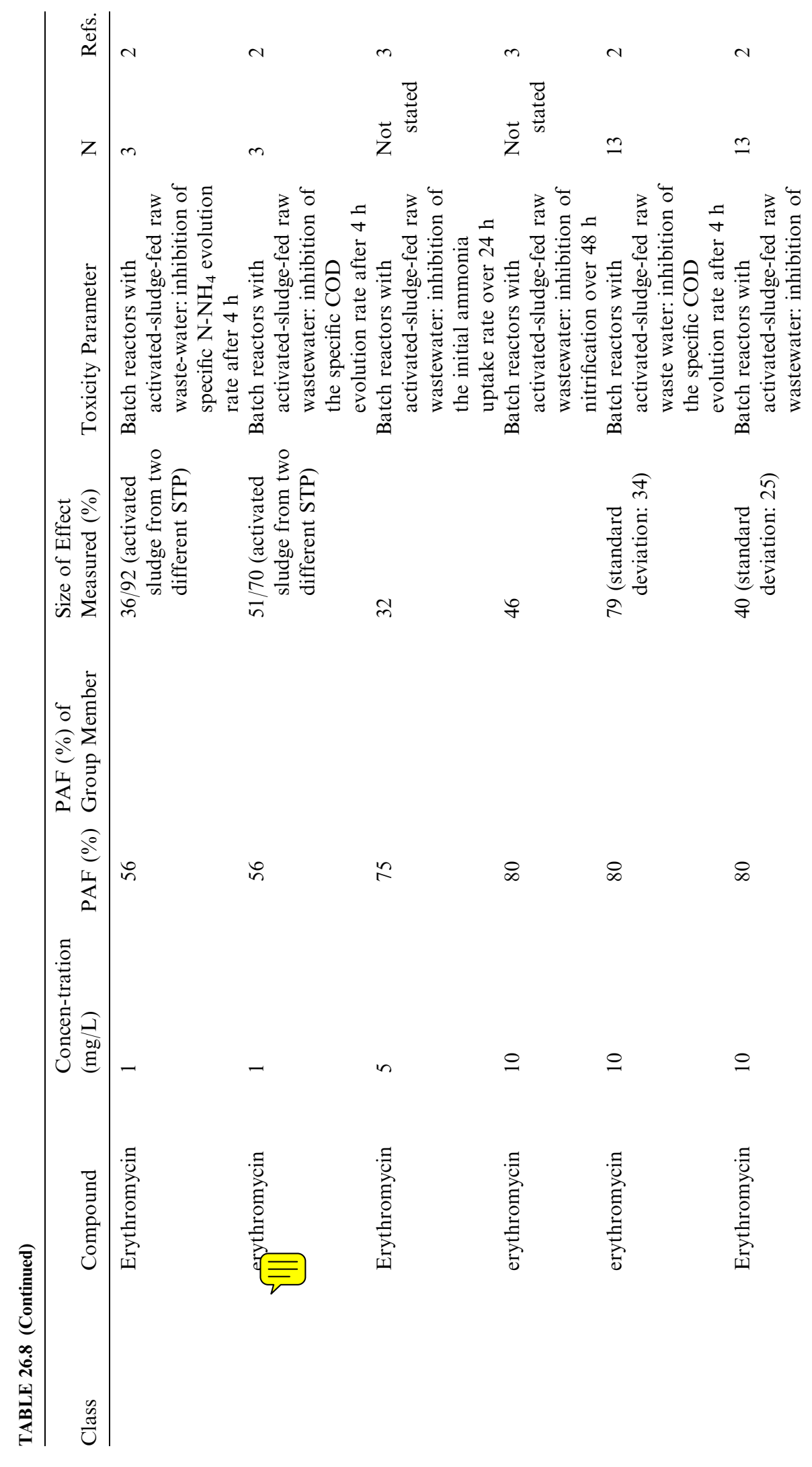




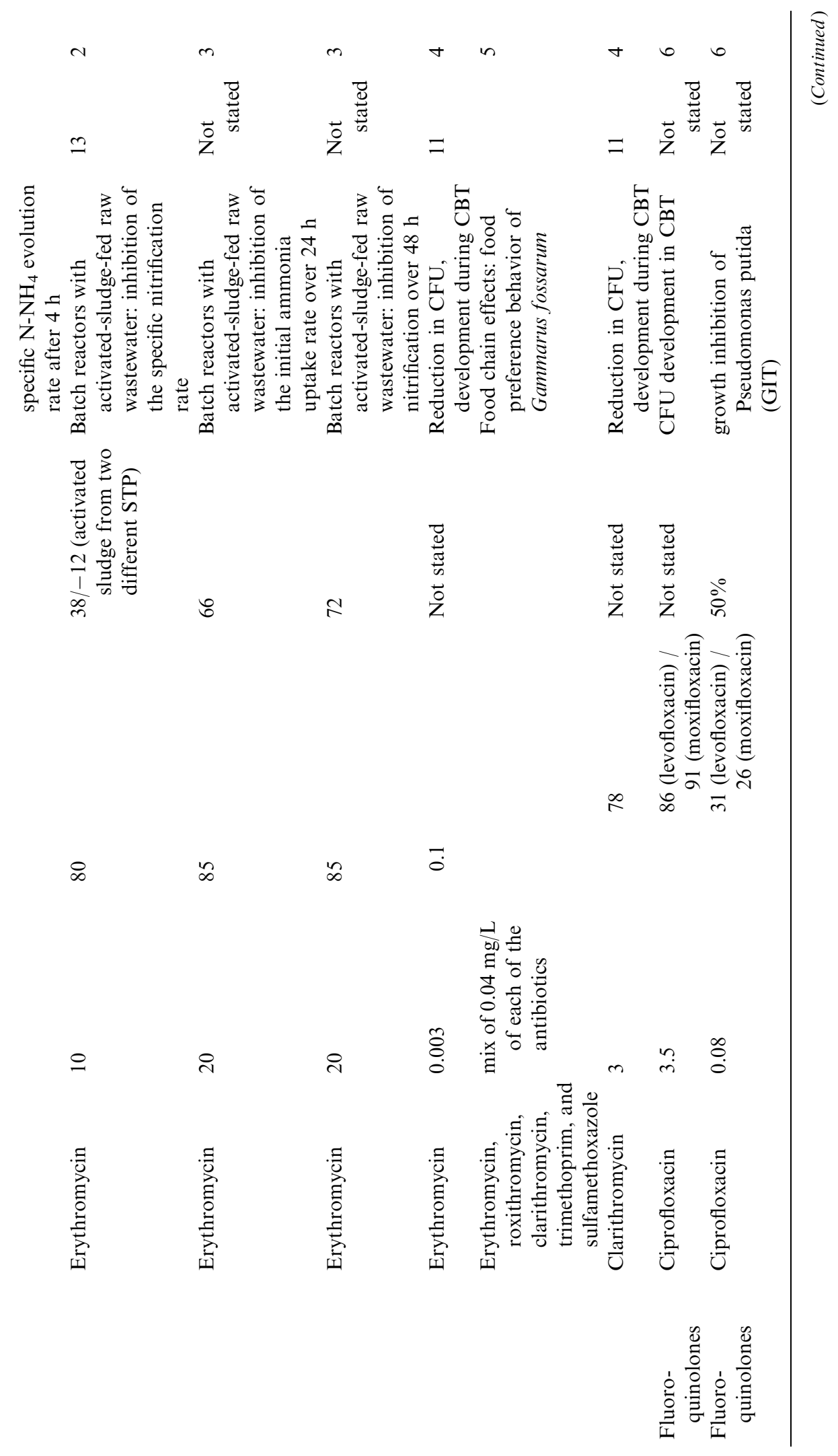




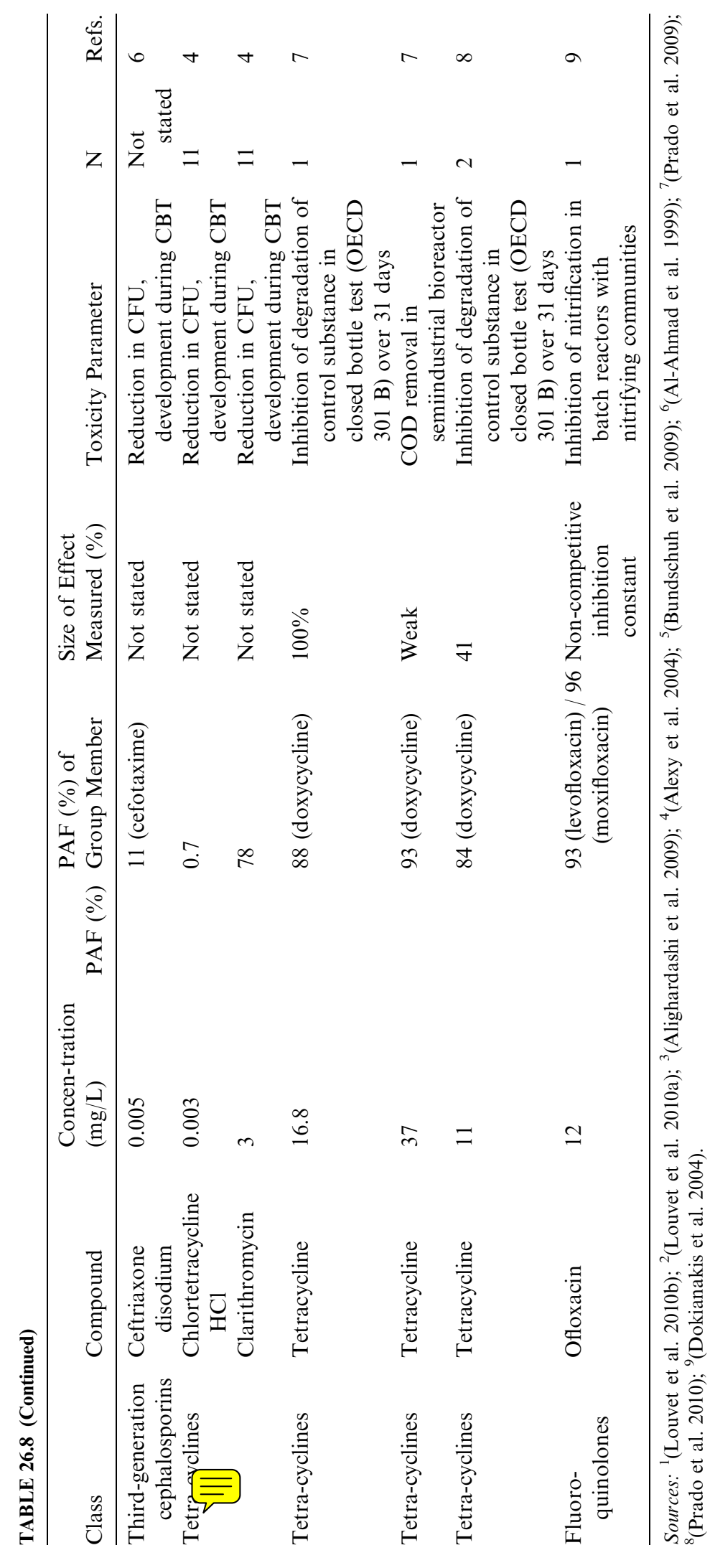


which is equivalent to a PAF of $0.2 \%$. Concentrations higher than $500 \mu \mathrm{g} / \mathrm{L}$ also inhibited nitrification. At $4 \mu \mathrm{g} / \mathrm{L}$, erythromycin-treated reactors showed higher nitrification as compared to control reactors. This was explained through the extra source of nitrogen provided by dead bacteria.

In contrast, Fan et al. (2009) found that erythromycin (at concentrations of 500 $\mu \mathrm{g} / \mathrm{L}$ or a single-substance PAF of $46 \%$ according to our calculations) did not have pronounced effects on nitrogen and phosphorus removal in sequencing batch reactors fed synthetic wastewater during long incubations (Fan et al., 2009). Still, phylogenetic investigations showed that the diversity of ammonium-oxidizing bacteria and of nitrifying bacteria had declined by up to $80 \%$, highlighting effects of the antibiotic on the composition of the functional community. Further, shortterm toxicity measurements with higher concentrations of erythromycin and $\mathrm{H}_{2} \mathrm{O}$-erythromycin showed that while the adapted nitrifier and ammonium oxidizer communities were more tolerant to high doses of antibiotics, functional parameters were still affected at concentrations equal or higher than the long-term concentration (Fan et al., 2009). Thus, shock concentrations of antibiotics during the onset of a pandemic might affect WWTP functioning, although almost all treatment plants will be acclimated to lower antibiotic concentrations during the predominant interpandemic period. Further, while relatively low concentrations of single antibiotics are able to select for equally functional, but less diverse, antibiotic-tolerant communities, the question remains as to whether joint effects of several antibiotics might further reduce diversity and therefore functioning.

As seen above, investigations with full-scale treatment plants sometimes show a high functional stability also for other antibiotics. Most relevant to this study, Al-Ahmad et al. (1999) found that a mixture of 12 antibiotics tested in laboratoryscale treatment plants did not have effects on DOC elimination during 84 days of operation, even at concentrations that were 100 times higher than average influent concentrations $\Rightarrow$ contrast, effects of a sudden change in wastewater composition were apparent五 two WWTPs purifying waste water from a pharmaceutical production site. Failure in ammonium oxidation and changes in the composition of ammonium-oxidizing bacterial communities were found when the plant started producing imidazoles, and problems continued for a few weeks (Wittebolle et al., 2005).

To conclude, congruence of modeled toxicity with experimental data on toxicity of shock loads of antibiotics suggests that a severe pandemic might indeed provide antibiotic concentrations capable of affecting microbial WWTP consortia, at least for a short time. This could compromise vital and obligate microbial functions such as nitrification, phosphorus, and COD removal. With longer exposure duration, changes in community composition, together with an increase in genetically encoded antibiotic resistance (see Section 1.3.2), might preserve WWTP functioning.

\subsubsection{Effects on Antibiotic Resistance}

The projected widespread use of antibacterials during an influenza pandemic introduces an opportunity for the rapid spread of antibiotic resistance. Bacteria can become resistant to antibiotics by mutations or the acquisition of appropriate genes from other microorganisms (Verhoef and Fluit, 2006). Many publications have shown that WWTPs are a hot spot for the occurrence of resistance genes (Schluter 
et al., 2003; Szczepanowski et al., 2009), showing that the human community discharges bacteria and mobile genetic elements carrying resistance genes to the WWTP in interpandemic times. Further, WWTPs have been discussed as environments for gene transfer between bacteria (Geisenberger et al., 1999), and the presence of residual antibiotics could speed such genetic exchange. In any case, massive use of antibiotics during the pandemic will further resistance development in human microbiota (Barlow, 2009), and a significant proportion of these will reach WWTPs and be discharged with WWTP effluent after incomplete purification.

An additional question is whether elevated concentrations of antibiotics during a pandemic might be high enough for selection and recombination of resistant bacteria in the WWTP. There is little experimental evidence to prove or disprove this idea, as most studies so far have investigated treatment plants that also received human waste, presumably containing resistant bacteria. However, recent investigations in WWTPs treating waste from antibiotic production sites showed that high concentrations of antibiotics can indeed select for resistant populations that can subsequently be discharged to the receiving rivers ( $\mathrm{Li}$ et al., 2009; 2010). In the first production plant, concentrations of penicillin $\mathrm{G}$ were around $150 \mu \mathrm{g} / \mathrm{L}$ (PAF of amoxicillin: $34 \%$ ). Extremely high MICs for $\beta$-lactam antibiotics were observed in isolates from the WWTP, while resistance to unrelated antibiotics was also elevated. In the second plant, which produced oxytetracycline $(30.5 \mathrm{mg} / \mathrm{L}$ in the sludge, equivalent to a doxycycline PAF of $92 \%$ ), extremely high MICs were again observed in isolates tested for resistance to different tetracyclines. Also, many isolates showed multiresistance to unrelated antibiotics. Isolates often contained class I integrons, genetic elements that can integrate a multitude of resistance genes into bacterial genomes. From these two studies, it indeed appears that antibiotics can select for resistance in WWTPs.

\subsection{CONCLUSIONS}

Through epidemiological simulations and environmental and toxicity modeling, the concentrations and effects of antibiotics during an influenza pandemic were determined. It was shown that a severe pandemic might affect WWTP consortia and lead to increased nitrogen and COD release, at least for short periods. Pandemic concentrations are also likely to increase antibiotic resistance beyond levels already observed in WWTP. In line with modeling results obtained for a mild pandemic, no widespread WWTP failures were observed during the 2009/2010 influenza pandemic. Still, current experimental data is insufficient to disprove possible effects during an influenza pandemic characterized by a higher infectivity.

\section{REFERENCES}

Ahrer W, Scherwenk E, Buchberger W (2001). Determination of drug residues in water by the combination of liquid chromatography or capillary electrophoresis with electrospray mass spectrometry. J Chromatogr A 910(1):69-78.

Al-Ahmad A, Daschner FD, Kümmerer K (1999). Biodegradability of cefotiam, ciprofloxacin, meropenem, penicillin $\mathrm{G}$, and sulfamethoxazole and inhibition of waste water bacteria. Arch Environ Contam Toxicol 37(2):158-163. 
Alexy R, Kumpel T, Kümmerer K (2004). Assessment of degradation of 18 antibiotics in the closed bottle test. Chemosphere 57(6):505-512.

Alexy R, Sommer A, Lange FT, Kümmerer K (2006). Local use of antibiotics and their input and fate in a small sewage treatment plant-Significance of balancing and analysis on a local scale vs. nationwide scale. Acta Hydrochim Hydrobiol 34(6):587-592.

Alighardashi A, Pandolfi D, Potier O, Pons MN (2009). Acute sensitivity of activated sludge bacteria to erythromycin. J Hazard Mater 172(2-3):685-692.

Anderson RM, May RM. 1991. Infectious Diseases of Humans: Dynamics and Control. Oxford University Press, Oxford.

Andreozzi R, Raffaele M, Nicklas P (2003). Pharmaceuticals in STP effluents and their solar photodegradation in aquatic environment. Chemosphere 50(10):1319-1330.

Ashton D, Hilton M, Thomas KV (2004). Investigating the environmental transport of human pharmaceuticals to streams in the United Kingdom. Sci Total Environ 333(1-3):167-184.

American Thoracic Society (ATS) (2005). Guidelines for the management of adults with hospital-acquired, ventilator-associated, and healthcare-associated pneumonia. $\mathrm{Am} \mathrm{J}$ Respir Crit Care Med 171:388-416.

Balcan D, Colizza V, Gonçalves B, Hu H, Ramasco JJ, Vespignani A (2009a). Multiscale mobility networks and the large scale spreading of infectious diseases. Proc Nat Acad Sci 106:21484-21489.

Balcan D, et al. (20090b). Modeling the critical care demand and antibiotics resources needed during the Fall 2009 wave of influenza A(H1N1) pandemic. PLoS Currents Influenza. Available: http://knol.google.com/k/duygubalcan/modeling-the-critical-care-demand-and/ 3cbpxfuorniyr/9. Accessed June 30, 2010.

Bannister B, Gillespie S, Jones J. (2006). Infection: Microbiology and Management, 3rd ed. Blackwell, Oxford.

Barlow GD (2009). Swine flu and antibiotics. J Antimicrob Chemother 64(5):889-894.

Barr IG, Deng YM, Iannello P, Hurt AC, Komadina N (in press). Adamantane resistance in influenza $\mathrm{A}(\mathrm{H} 1)$ viruses increased in 2007 in South East Asia but decreased in Australia and some other countries. Antiviral Res.

Batt AL, Aga DS (2005). Simultaneous analysis of multiple classes of antibiotics by ion trap LC/ MS/MS for assessing surface water and groundwater contamination. Anal Chem 77:2940-2947.

Batt AL, Bruce IB, Aga DS (2006). Evaluating the vulnerability of surface waters to antibiotic contamination from varying wastewater treatment plant discharges. Environ Pollut 142(2):295-302.

Batt AL, Kim S, Aga DS (2007). Comparison of the occurrence of antibiotics in four full-scale wastewater treatment plants with varying designs and operations. Chemosphere 68(3):428-435.

Bendz D, Paxeus NA, Ginn TR, Loge FJ (2005). Occurrence and fate of pharmaceutically active compounds in the environment, a case study: Hoje River in Sweden. J Hazard Mater 122(3):195-204.

Benotti MJ, Brownawell BJ (2009). Microbial degradation of pharmaceuticals in estuarine and coastal seawater. Environ Pollut 157(3):994-1002.

Bound JP, Voulvoulis N (2006). Predicted and measured concentrations for selected pharmaceuticals in UK rivers: Implications for risk assessment. Water Res 40(15):2885-2892.

Brain RA, et al. (2004a.) Microcosm evaluation of the effects of an eight pharmaceutical mixture to the aquatic macrophytes Lemna gibba and Myriophyllum sibiricum. Aquatic Toxicolo 70(1):23-40.

Brain RA, Johnson DJ, Richards SM, Sanderson H, Sibley PK, Solomon KR (2004b). Effects of 25 pharmaceutical compounds to Lemna gibba using a seven-day static-renewal test. Environ Toxicol Chem 23(2):371-382. 
Brown KD, Kulis J, Thomson B, Chapman TH, Mawhinney DB (2006). Occurrence of antibiotics in hospital, residential, and dairy effluent, municipal wastewater, and the Rio Grande in New Mexico. Sci Total Environ 366(2-3):772-783.

Brun GL, Bernier M, Losier R, Doe K, Jackman P, Lee H-B (2006). Pharmaceutically active compounds in Atlantic Canadian sewage treatment plant effluents and receiving waters, and potential for environmental effects as measured by acute and chronic aquatic toxicity. Environ Toxicol Chemi 25(8):2163-2176.

Brundage JF (2006). Interactions between influenza and bacterial respiratory pathogens: Implications for pandemic preparedness. Lancet Infecti Dis 6(5):303-312.

Brundage JF, Shanks GD (2008). Deaths from bacterial pneumonia during 1918-19 influenza pandemic. Emerg Infect Dis 14(8):1193-1198.

Bundschuh M, Hahn T, Gessner MO, Schulz R (2009). Antibiotics as a chemical stressor affecting an aquatic decomposer-detritivore system. Environ Toxicol Chem 28(1):197-203.

Buser HR, Poiger T, Muller MD (1998). Occurrence and fate of the pharmaceutical drug diclofenac in surface waters: Rapid photodegradation in a lake. Environ Sci Technol 32(22):3449-3456.

Cabinet Office (2008). National Risk Register. Available: http://www.cabinetofficegovuk/ / media/assets/www.cabinetofficegovuk/publications/reports/national_risk_register/national_ risk_register $\%$ 20pdfashx.

Carballa M, et al. (2004). Behavior of pharmaceuticals, cosmetics and hormones in a sewage treatment plant. Water Res 38(12):2918-2926.

Carlsson C, Johansson A-K, Alvan G, Bergman K, Kuhler T (2006). Are pharmaceuticals potent environmental pollutants? Part I: Environmental risk assessments of selected active pharmaceutical ingredients. Sci Total Environ 364(1-3):67-87.

Choi K-J, Kim S-G, Kim C-w, Kim S-H (2007). Determination of antibiotic compounds in water by on-line SPE-LC/MSD. Chemosphere 66(6):977-984.

Christensen FM (1998). Pharmaceuticals in the environment: A human risk. Regul Toxicol Pharmacol 28:212-221.

Coenen S, et al. (2006). European surveillance of antimicrobial consumption (ESAC): Outpatient cephalosporin use in Europe. J Antimicrob Chemother 58(2):413-417.

Conleya JM, Symes SJ, Kindelberger SA, Richards SM (2008). Rapid liquid chromatographytandem mass spectrometry method for the determination of a broad mixture of pharmaceuticals in surface water. J Chromatogr A 1185(2):206-215.

Cordy GE, et al. (2004). Do pharmaceuticals, pathogens, and other organic waste water compounds persist when waste water is used for recharge? Ground Water Monitor Remediat 24(2):58-69.

Costanzo SD, Murby J, Bates J (2005). Ecosystem response to antibiotics entering the aquatic environment. Marine Pollut Bull 51(1-4):218-223.

de Neeling AJ, Overbeek BP, Horrevorts AM, Ligtvoet EEJ, Goettsch WG (2001). Antibiotic use and resistance of Streptococcus pneumoniae in The Netherlands during the period 1994-1999. J Antimicrob Chemother 48(3):441-444.

Department of Health (2007). Government launches new flu pandemic plan. Available:http:// ndscoigovuk/environment/fullDetailasp?ReleaseID $=332808 \&$ NewsAreaID $=2 \&$ Navigated FromDepartment=False. Accessed July 16, 2008.

Department of Health and Human Services, Department of Homeland Security (2007). Draft guidance on allocating and targeting pandemic influenza vaccine. Available: http://www. pandemicflugov/vaccine/prioritizationpdf.

De Zwart D, Posthuma L (2005). Complex mixture toxicity for single and multiple species: Proposed methodologies. Environ Toxicol Chem 24(10):2665-2676. 
Dokianakis SN, Kornaros ME, Lyberatos G (2004). On the effect of pharmaceuticals on bacterial nitrite oxidation. Water Sci Technol 50(5):341-346.

Dollery C. 1999. Therapeutic Drugs, 2nd ed. Harcourt Brace, London.

Drewes JE, Heberer T, Rauch T, Reddersen K (2003). Fate of pharmaceuticals during ground water recharge. Ground Water Monitor Remediat 23(3):64-72.

Environment Agency (EA) (2003). Targeted monitoring programme for pharmaceuticals in the aquatic environment. R\&D Technical Report P6-012/06/TR. EA, Bristol.

EUCAST (2009). Antimicrobial wild type distributions of microorganisms. Available: http:// 217703399/Eucast2/. Accessed January 12, 2010.

European Chemicals Agency (2008). Guidance on information requirements and chemical safety assessment, Chapter R.10: Characterisation of dose [concentration]-response for environment.

European Influenza Surveillance Scheme (2008). Pandemic plans on the Internet. Available: http://www.eissorg/html/pandemic_planshtml. Accessed July 16, 2008.

European Surveillance of Antimicrobial Consumption project (ESAC) (2006). ESAC interactive database. Available: http://www.esacuaacbe/esac_service/applet/eidbhtml.

Fan C, et al. (2009). Influence of trace erythromycin and eryhthromycin- $\mathrm{H}_{2} \mathrm{O}$ on carbon and nutrients removal and on resistance selection in sequencing batch reactors (SBRs). Appl Microbiol Biotechnol 85(1):185-195.

Ferech M, et al. (2006). European surveillance of antimicrobial consumption (ESAC): Outpatient penicillin use in Europe. J Antimicrob Chemother 58(2):408-412.

Fowler RA, et al. (2005). Cost-effectiveness of defending against bioterrorism: A comparison of vaccination and antibiotic prophylaxis against anthrax. Ann Intern Med 142(8):601-610.

García-Rey C, Aguilar L, Baquero F, Casal J, Dal-Re R (2002). Importance of local variations in antibiotic consumption and geographical differences of erythromycin and penicillin resistance in Streptococcus pneumoniae. J Clin Microbiol 40(1):159-164.

Gartiser S, Urich E, Alexy R, Kümmerer K (2007). Ultimate biodegradation and elimination of antibiotics in inherent tests. Chemosphere 67(3):604-613.

Geisenberger O, Ammendola A, Christensen BB, Molin Sr, Schleifer K-H, Eberl L (1999). Monitoring the conjugal transfer of plasmid RP4 in activated sludge and in situ identification of the transconjugants. FEMS Microbiol Lett 174(1):9-17.

Giger W, et al. (2003). Occurrence and fate of antibiotics as trace contaminants in wastewaters, sewages ludges, and surface waters. CHIMIA Int J Chem 57:485-491.

Golet EM, Alder AC, Hartmann A, Ternes TA, Giger W (2001). Trace determination of fluoroquinolone antibacterial agents in urban wastewater by solid-phase extraction and liquid chromatography with fluorescence detection. Anal Chem 73(15):3632-3638.

Gomez MJ, Martinez Bueno MJ, Lacorte S, Fernandez-Alba AR, Aguera A (2007). Pilot survey monitoring pharmaceuticals and related compounds in a sewage treatment plant located on the Mediterranean coast. Chemosphere 66(6):993-1002.

Gulkowska A, et al. (2008). Removal of antibiotics from wastewater by sewage treatment facilities in Hong Kong and Shenzhen, China. Water Res 42(1-2):395-403.

Gupta RK, George R, Nguyen-Van-Tam JS (2008). Bacterial pneumonia and pandemic influenza planning. Emerg Infect Dis 14(8):1187-1192.

Haggard BE, Galloway JM, Green WR, Meyer MT (2006). Pharmaceuticals and other organic chemicals in selected North-Central and Northwestern Arkansas streams. J Environ Qual 35(4):1078-1087.

Hampson AW (2008). Vaccines for pandemic influenza. The history of our current vaccines, their limitations and the requirements to deal with a pandemic threat. Ann Acad Med Singapore 37(6):510-518. 
He G, Massarella J, Ward P (1999). Clinical pharmacokinetics of the prodrug oseltamivir and its active metabolite Ro 64-0802. Clin Pharmacokinet 37(6):471-484.

Heberer T (2002). Tracking persistent pharmaceutical residues from municipal sewage to drinking water. J Hydrol 266(3-4):175-189.

Hirsch R, Ternes T, Haberer K, Kratz K-L (1999). Occurrence of antibiotics in the aquatic environment. Sci Total Environ 225(1-2):109-118.

Hurd HS, Raef TA (2010). ISU Associate Professor and Former USDA Deputy Undersecretary Food Safety Responds to CBS News Segments on Antibiotics-Feb. 9 and 10. Available: http://vetmediastateedu/news/isu-associate-professor-and-former-usda-deputyundersecretary-food-safety-responds-cbs-news-seg.

Hurt AC, Selleck P, Komadina N, Shaw R, Brown L, Barr IG (2007). Susceptibility of highly pathogenic A(H5N1) avian influenza viruses to the neuraminidase inhibitors and adamantanes. Antiviral Res 73(3):228-231.

Jefferson T (2007). Look at all the evidence before stockpiling amantadine. BMJ 334 (7591):439-b-

Jones OAH, Voulvoulis N, Lester JN (2002). Aquatic environmental assessment of the top 25 English prescription pharmaceuticals. Water Res 36(20):5013-5013.

Jones-Lepp TL (2006). Chemical markers of human waste contamination: Analysis of urobilin and pharmaceuticals in source waters. J Environ Monitor 8:472-478.

Joss A, et al. (2006). Biological degradation of pharmaceuticals in municipal wastewater treatment: Proposing a classification scheme. Water Res 40(8):1686-1686.

Junker T, Alexy R, Knacker T, Kümmerer K (2006). Biodegradability of ${ }^{14}$ C-labeled antibiotics in a modified laboratory scale sewage treatment plant at environmentally relevant concentrations. Environ Sci Technol 40(1):318-324.

Kaiser L, Wat C, Mills T, Mahoney P, Ward P, Hayden F (2003). Impact of oseltamivir treatment on influenza-related lower respiratory tract complications and hospitalizations. Arch Intern Med 163(14): 1667-1672.

Kamigaki T, Oshitani H (2009). Epidemiological characteristics and low case fatality rate of pandemic (H1N1) 2009 in Japan. PLoS Curr 1:RRN1139.

Kati WM, et al. (2002). In vitro characterization of A-315675, a highly potent inhibitor of A and B strain influenza virus neuraminidases and influenza virus replication. Antimicrob Agents Chemother 46(4):1014-1021.

Kim SD, Cho J, Kim IS, Vanderford BJ, Snyder SA (2007). Occurrence and removal of pharmaceuticals and endocrine disruptors in South Korean surface, drinking, and waste waters. Water Res 41(5):1013-1021.

Kolpin DW, et al. (2002). Pharmaceuticals, hormones, and other organic wastewater contaminants in U.S. streams, 1999-2000: A national reconnaissance. Environ Sci Technol 36(6):1202-1211.

Kramarz P, Monnet D, Nicoll A, Yilmaz C, Ciancio B (2009). Use of oseltamivir in 12 European countries between 2002 and 2007-Lack of association with the appearance of oseltamivir-resistant influenza A(H1N1) viruses. Euro Surveill 14(5).

Kümmerer K (2009a). Antibiotics in the aquatic environment-A review-Part I. Chemosphere 75(4):417-434.

Kümmerer K (2009b). Antibiotics in the aquatic environment-A review-Part II. Chemosphere 75(4):435-441.

Kümmerer K, Al-Ahmad A, Mersch-Sundermann V (2000). Biodegradability of some antibiotics, elimination of the genotoxicity and affection of wastewater bacteria in a simple test. Chemosphere 40(7):701-710. 
Li D, et al. (2009). Antibiotic-resistance profile in environmental bacteria isolated from penicillin production wastewater treatment plant and the receiving river. Environ Microbiol 11(6):1506-1517.

Li D, et al. (2010). Antibiotic resistance characteristics of environmental bacteria from an oxytetracycline production wastewater treatment plant and the receiving river. Appl Environ Microbiol 76(11):3444-3451.

Liebig M, Moltmann JF, Knacker T (2006). Evaluation of measured and predicted environmental concentrations of selected human pharmaceuticals and personal care products. Environ Sci Pollut Res 13(2):110-119.

Lim WS (2007). Pandemic flu: Clinical management of patients with an influenza-like illness during an influenza pandemic. Thorax 62(Suppl1):1-46.

Lindberg RH, Bjorklund K, Rendahl P, Johansson MI, Tysklind M, Andersson BAV (2007). Environmental risk assessment of antibiotics in the Swedish environment with emphasis on sewage treatment plants. Water Res 41(3):613-619.

Lindqvist N, Tuhkanen T, Kronberg L (2005). Occurrence of acidic pharmaceuticals in raw and treated sewages and in receiving waters. Water Res 39(11):2219-2228.

Lishman L, et al. (2006). Occurrence and reductions of pharmaceuticals and personal care products and estrogens by municipal wastewater treatment plants in Ontario, Canada. Sci Total Environ 367(2-3):544-558.

Louria DB, Blumenfeld HL, Ellis JT, Kilbourne ED, Rogers DE (1959). Studies on influenza in the pandemic of 1957-1958. II. Pulmonary complications of influenza. J Clin Invest 38(1 Pt 1-2):213-265.

Louvet JN, Giammarino C, Potier O, Pons MN (2010a). Adverse effects of erythromycin on the structure and chemistry of activated sludge. Environ Pollut 158(3):688-693.

Louvet JN, Heluin Y, Attik G, Dumas D, Potier O, Pons MN (2010b). Assessment of erythromycin toxicity on activated sludge via batch experiments and microscopic techniques (epifluorescence and CLSM). Process Biochem 45(11):1787-1794.

McArdell CS, Molnar E, Suter MJF, Giger W (2003). Occurrence and fate of macrolide antibiotics in wastewater treatment plants and in the Glatt Valley Watershed, Switzerland. Environ Sci Technol 37(24):5479-5486.

Meltzer MI, Cox NJ, Fukuda K (1999). The economic impact of pandemic influenza in the United States: Priorities for intervention. Emerg Infect Dis 5(5):659-671.

Metcalfe CD, Miao XS, Koenig BG, Struger J (2003). Distribution of acidic and neutral drugs in surface waters near sewage treatment plants in the lower Great Lakes, Canada. Environ Toxicol Chem 22(12):2881-2889.

Miao X-S, Metcalfe CD (2003). Determination of cholesterol-lowering statin drugs in aqueous samples using liquid chromatography-electrospray ionization tandem mass spectrometry. $J$ Chromatogr $A$ 998(1-2):133-141.

Miao XS, Bishay F, Chen M, Metcalfe CD (2004). Occurrence of antimicrobials in the final effluents of wastewater treatment plants in Canada. Environ Sci Technol 38(13):3533-3541.

Moldovan Z (2006). Occurrences of pharmaceutical and personal care products as micropollutants in rivers from Romania. Chemosphere 4(11):1808-1817.

Morens DM, Taubenberger JK, Fauci AS (2008). Predominant role of bacterial pneumonia as a cause of death in pandemic influenza: Implications for pandemic influenza preparedness. J Infect Dis 198(7):962-970.

Morse SS (2007). The US pandemic influenza implementation plan at six months. Nat Med 13 (6):681-684.

Mounier-Jack S, Coker R (2006). Pandemic influenza: Are Europe's institutions prepared? Eur J Public Health 16(2):119-120. 
Muller A, Coenen S, Monnet DL, Goossens H, group TEp (2007). European surveillance of antimicrobial consumption (ESAC): Outpatient antibiotic use in Europe, 1998-2005. Eurosurveillance 12(41):1.

Nap RE, Andriessen MPHM, Meessen NEL, van der Werf TS (2007). Pandemic influenza and hospital resources. Emerg Infect Dis 13(11). Available:http://www.cdc.gov/EID/content/13/ 11/1714.htm.

NAS (2008). Antivirals for pandemic influenza: Guidance on developing a distribution and dispensing program. Available: http://booksnapedu/openbookphp?record_id $=12170 \&$ page $=\mathrm{R} 1$.

National Centers for Coastal Ocean Science (19xx). Pharmaceuticals in the environment, information for assessing risk. Available:http://www.chbrnoaagov/peiar/defaultaspx.

New England Journal of Medicine Editors (2009). When to consider the use of antibiotics in the treatment of $2009 \mathrm{H} 1 \mathrm{~N} 1$ influenza-associated pneumonia. $N$ Engl J Med. Available: http://h1n1.nejm.org/?p=1234\&query $=$ TOC\#.

Newman M, Ownby D, Mezin L, Powell D, Christensen T, Lerberg S (2002). Species sensitivity distributions in ecological risk assessment: Distributional assumptions, alternate bootstrap techniques and estimation of adequate number of species. In L. Posthuma, G. Suter, and T Traas (Eds), Species Sensitivity Distributions in Ecotoxicology, CRC Press, Boca Raton, FL, p. 616.

NHS BSA (2008). Prescribing analysis charts: National antibiotics charts. Available:http:// www.nhsbsa.nhs.uk/PrescriptionServices/Documents/NPC_Antibiotics_July_2008.ppt. Accessed June 30, 2010.

Nicholson KG, et al. (2000). Efficacy and safety of oseltamivir in treatment of acute influenza: A randomised controlled trial. Neuraminidase Inhibitor Flu Treatment Investigator Group. Lancet 355(9218):1845-1850.

Ong AK, Hayden FG (2007). John F. Enders Lecture 2006: Antivirals for Influenza. J Infect Dis 196(2):181-190.

Osterholm M (2005). Preparing for the next pandemic. Foreign Affairs 84. Available:http:// www.foreignaffairs.org/20050701 faessay84402/michael-t-osterholm/preparing-for-the-nextpandemic.html.

Peltola Ville T, Murti KG, McCullers Jonathan A (2005). Influenza virus neuraminidase contributes to secondary bacterial pneumonia. J Infect Dis 192(2):249-257.

Pharmaceuticals B (2007). Biocryst awarded \$102.6 million from U.S. Department of Health an Human Services to develop Peramivir for seasonal and pandemic influenza.

Prado N, Ochoa J, Amrane A (2009). Biodegradation by activated sludge and toxicity of tetracycline into a semi-industrial membrane bioreactor. Bioresource Technol 100(15):3769-3774.

Prado N, Montéléon C, Ochoa J, Amrane A (2010). Evaluation of the toxicity of veterinary antibiotics on activated sludge using modified Sturm tests - Application to tetracycline and tylosine antibiotics. J Chem Technol Biotechnol 85(4):471-477.

Priest P, Yudkin P, McNulty C, Mant D, Wise R (2001). Antibacterial prescribing and antibacterial resistance in English general practice: cross sectional study commentary: Antibiotic resistance is a dynamic process. BMJ 323(7320):1037-1041.

Public Health Agencyof Canada (2004). Canadian pandemic influenza plan for the health sector. Annex G, health services: Clinical care guidelines and tools, Appendix 5. IV. Antibiotics. Available:http://www.phac-aspcgcca/cpip-pclcpi/pdf-e/16-CPIP-Appendix-GClinical_epdf. Accessed July 28, 2008.

Rabiet M, Togola A, Brissaud F, Seidel JL, Budzinski H, Elbaz-Poulichet F (2006). Consequences of treated water recycling as regards pharmaceuticals and drugs in surface and ground waters of a medium-sized Mediterranean catchment. Environ Sci Technol 40 (17):5282-5288. 
Rainsford K (2006). Influenza ("Bird Flu"), inflammation and anti-inflammatory/analgesic drugs. Inflammopharmacology 14(1):2-9.

Reemtsma T, et al. (2006). Polar pollutants entry into the water cycle by municipal wastewater: A European perspective. Environ Sci Technol 40(17):5451-5458.

Reuters (2007). Roche gives workers flu drug in case of pandemic. Available:http://www. reuterscom/article/governmentFilingsNews/idUSN0834658920070308? pageNumber $=1$. Accessed March 8, 2007.

Roberts PH, Thomas KV (2006). The occurrence of selected pharmaceuticals in wastewater effluent and surface waters of the lower Tyne catchment. Sci Total Environ 356(1-3):143-153.

Roche H-L (2007). Tamiflu: Pharmacological properties. Available:http://emcmedicinesorguk/ emc/industry $/$ defaultasp?page $=$ displaydocasp\&documentid $=10446$. Updated September 12, 2007.

Roche Group (2006). Factsheet Tamiflu. March 20.

Sacher F, Lange FT, Brauch H-J, Blankenhorn I (2001). Pharmaceuticals in groundwaters: Analytical methods and results of a monitoring program in Baden-Wurttemberg, Germany. J Chromatogr A 938(1-2): 199-210.

Salomon R, Hoffmann E, Webster RG (2007). Inhibition of the cytokine response does not protect against lethal H5N1 influenza infection. PNAS 104(30):12479-12481.

Schluter A, et al. (2003). The 64508 bp IncP-1\{beta\} antibiotic multiresistance plasmid pB10 isolated from a waste-water treatment plant provides evidence for recombination between members of different branches of the IncP-1\{beta\} group. Microbiology 149(11):3139-3153.

Schwarzmann SW, Sullivan RJ (1971). Bacterial pneumonia during the Hong Kong influenza epidemic of 1968-1969. Arch Internal Med 127:1037-1041.

Singer AC, Nunn MA, Gould EA, Johnson AC (2007). Potential risks associated with the widespread use of tamiflu. Environ Health Perspect 115(1):102-106.

Singer AC, et al (Submitted). Assessing teh ecotoxicologic hazards of a pandemic influenza medical response. Environ Health Perspect.

Siquier B, et al. (2006). Efficacy and safety of twice-daily pharmacokinetically enhanced amoxicillin/clavulanate $(2000 / 125 \mathrm{mg})$ in the treatment of adults with community-acquired pneumonia in a country with a high prevalence of penicillin-resistant Streptococcus pneumoniae. J Antimicrob Chemother 57(3):536-545.

Smith DL, Harris AD, Johnson JA, Silbergeld EK, Morris JG Jr (2002). Animal antibiotic use has an early but important impact on the emergence of antibiotic resistance in human commensal bacteria. PNAS 99(9):6434-6439.

Stackelberg PE, Furlong ET, Meyer MT, Zaugg SD, Henderson AK, Reissman DB (2004). Persistence of pharmaceutical compounds and other organic wastewater contaminants in a conventional drinking-water-treatment plant. Sci Total Environ 329(1-3):99-113.

Szczepanowski R, et al. (2009). Detection of 140 clinically relevant antibiotic-resistance genes in the plasmid metagenome of wastewater treatment plant bacteria showing reduced susceptibility to selected antibiotics. Microbiology 155(7):2306-2319.

ter Laak TL, van der Aa M, Houtman CJ, Stoks PG, van Wezel AP (2010). Relating environmental concentrations of pharmaceuticals to consumption: A mass balance approach for the river Rhine. Environ Int 36(5):403-409.

Ternes TA (1998). Occurrence of drugs in German sewage treatment plants and rivers. Water Res 32(11):3245-3260.

Ternes TA (2001). Analytical methods for the determination of pharmaceuticals in aqueous environmental samples. TrAC Trends Anal Chem 20(8):419-434.

Ternes TA, et al. (2002). Removal of pharmaceuticals during drinking water treatment. Environ Sci Technol 36(17):3855-3863. 
Thomas KV, Hilton M (2003). Targeted monitoring programme for pharmaceuticals in the aquatic environment. UK Environment Agency R\&D Technical Report P6-012/06. Environment Agency, United Kingdom.

Tierney E, Reddy D (2007). Roche media briefing: Update on current developments around Tamiflu (Basel, 26 April 2007). Available:http://www.rochecom/media/events/media-briefingtamiflu-2007htm. Accessed January 12, 2010.

Tixier C, Singer HP, Oellers S, Muller SR (2003). Occurrence and fate of carbamazepine, clofibric acid, diclofenac, ibuprofen, ketoprofen, and naproxen in surface Waters. Environ Sci Technol 37(6):1061-1068.

Treanor JJ, et al. (2000). Efficacy and Safety of the oral neuraminidase inhibitor oseltamivir in treating acute influenza. JAMA 283(8):1016-1024.

Trenholm RA, Vanderford BJ, Holady JC, Rexing DJ, Snyder SA (2006). Broad range analysis of endocrine disruptors and pharmaceuticals using gas chromatography and liquid chromatography tandem mass spectrometry. Chemosphere 65(11):1990-1998.

U.S. Centers for Disease Control and Prevention (2007). Interim pre-pandemic planning guidance: Community strategy for pandemic influenza mitigation in the United States: Early, targeted, layered use of nonpharmaceutical interventions. Available:http://healthvermontgov/panflu/documents/0207interimguidancepdf.

Uscher-Pines L, Omer SB, Barnett DJ, Burke TA, Balicer RD (2006). Priority setting for pandemic influenza: An analysis of national preparedness plans. PLoS Medi 3(10):e436.

UK Department of Health (2007a). Pandemic flu: A national framework for responding to an influenza pandemic (22 November). Available:http://www.dhgovuk/en/Publicationsandstatistics/Publications/PublicationsPolicyAndGuidance/dh_080734. Accessed October 2, 2009a.

UK Department of Health (2007b). The use of antibiotics for pandemic influenza: Scientific evidence base. (Available:http://www.dh.gov.uk/prod_consum_dh/groups/dh_digitalassets/@dh/@en/documents/digitalasset/dh_077274.pdf. Accessed June 30, 2010.

UK Department of Health (2009). Swine Flu: UK planning assumptions. Available:http:// www.dh.gov.uk/en/Publicationsandstatistics/Publications/PublicationsPolicyAndGuidance/DH_104844. Accessed April 7, 2010.

US Department of Health and Human Services (HHS) (2005). Pandemic influenza plan. Available:http://www.hhs.gov/pandemicflu/plan/pdf/HHSPandemicInfluenzaPlan.pdf. Accessed June 30, 2010.

U.S. Department of Health and Human Services (HHS) (2006). Pandemic flu planning checklist for individuals and families. Available:http://www.pandemicflugov/plan/individual/checklisthtml. Accessed July 7, 2008.

U.S. Department of Health and Human Services (HHS) (2007). Community strategy for pandemic influenza mitigation. Availale: http://www.pandemicflugov/plan/community/ commitigationhtml\#IV. Accessed July 14, 2008.

U.S. Department of Health and Human Services (HHS) (2008). HHS awards contracts for the development of faster influenza diagnostic tests. Available:http://www.hhsgov/news/press/ 2008pres/06/20080612ahtml. Accessed July 7, 2008.

U.S. Environmental Protection Agency (2007). Estimation Program Interface (EPI) Suite v3.2. Available:http://www.epagov/oppt/exposure/pubs/episuitehtm. Accessed January 12, 2010.

U.S. Homeland Security Council (2007). National strategy for pandemic influenza: Implementation plan one year summary. Available:http://snipurlcom/2okhb.

Verhoef J, Fluit A (2006). Surveillance uncovers the smoking gun for resistance emergence. Biochem Pharmacol 71(7):1036-1036.

Vieno NM, Tuhkanen T, Kronberg L (2005). Seasonal variation in the occurrence of pharmaceuticals in effluents from a sewage treatment plant and in the recipient water. Environ Sci Technol 39(21):8220-8226. 
Vieno NM, Tuhkanen T, Kronberg L (2006). Analysis of neutral and basic pharmaceuticals in sewage treatment plants and in recipient rivers using solid phase extraction and liquid chromatography-tandem mass spectrometry detection. J Chromatogr A 1134(1-2):101-111.

Wan H, et al. (2008). Replication and transmission of H9N2 influenza viruses in ferrets: Evaluation of pandemic potential. PLoS ONE 3(8): e2923.

Wennmalm AGB (2005). Public health care management of water pollution with pharmaceuticals: Environmental classification and analysis of pharmaceutical residues in sewage water. Drug Inform J 39(3).

Whitley RJ, et al. (2001). Oral oseltamivir treatment of influenza in children. Pediat Infect Dis $J$ 20(2):127-133.

Wiegel S, et al. (2004). Pharmaceuticals in the river Elbe and its tributaries. Chemosphere 57 (2):107-126.

Wishart DS, et al. (2006). DrugBank: A comprehensive resource for in silico drug discovery and exploration. Nucl Acids Res 34(Suppl 1):D668-672.

Wittebolle L, Boon N, Vanparys B, Heylen K, De Vos P, Verstraete W (2005). Failure of the ammonia oxidation process in two pharmaceutical wastewater treatment plants is linked to shifts in the bacterial communities. J Appl Microbiol 99(5):997-1006.

World Health Organization (WHO) (2004). The anatomical therapeutic chemical classification system with defined daily doses (ATC/DDD). Available:http://www.whocc.no/atcddd/ indexdatabase/index.php. Accessed July 8, 2008.

World Health Organization (WHO) (2005). WHO global influenza preparedness plan. Available:http://www.whoint/csr/resources/publications/influenza/GIP_2005_5Ewebpdf.

World Health Organization (WHO) (2006a). Global pandemic influenza action plan to increase vaccine supply. Available:http://www.whoint/csr/resources/publications/influenza/CDS_EPR_GIP_2006_1pdf.

World Health Organization (WHO) (2006b). World Health Organization pandemic influenza draft protocol for rapid response and containment (Updated draft 17 March 2006). Available:http://tinyurlcom/g5col. Accessed May, 152008.

World Health Organization (WHO) (2007). The World Health Report: A safer future: Global health security in the 21st century. Available:http://www.whoint/whr/2007/whr07_enpdf.

Yang S, Carlson K (2003). Evolution of antibiotic occurrence in a river through pristine, urban and agricultural landscapes. Water Res 37(19):4645-4656.

Zuccato E, Calamari D, Natangelo M, Fanelli R (2000). Presence of therapeutic drugs in the environment. Lancet 355(9217):1789-1789. 
